Article

\title{
Design, Synthesis, Molecular Docking, and Biological Evaluation of Pyrazole Hybrid Chalcone Conjugates as Potential Anticancer Agents and Tubulin Polymerization Inhibitors
}

\author{
Md. Jahangir Alam ${ }^{1}\left(\mathbb{D}\right.$, Ozair Alam ${ }^{1, *(\mathbb{D},}$, Ahmad Perwez ${ }^{2}$, Moshahid Alam Rizvi ${ }^{2}$, Mohd Javed Naim ${ }^{1}$, \\ Vegi G. M. Naidu ${ }^{3} \mathbb{D}$, Mohd Imran ${ }^{4}\left(\mathbb{D}\right.$, Mohammed M. Ghoneim ${ }^{5} \mathbb{D}$, Sultan Alshehri ${ }^{6}$ and Faiyaz Shakeel $^{6}$
}

check for updates

Citation: Alam, M.J.; Alam, O.; Perwez, A.; Rizvi, M.A.; Naim, M.J.; Naidu, V.G.M.; Imran, M.; Ghoneim, M.M.; Alshehri, S.; Shakeel, F. Design, Synthesis Molecular Docking, and Biological Evaluation of Pyrazole Hybrid Chalcone Conjugates as Potential Anticancer Agents and Tubulin Polymerization Inhibitors. Pharmaceuticals 2022, 15, 280. https://doi.org/10.3390/ph15030280

Academic Editor: Valentina Onnis

Received: 29 December 2021

Accepted: 11 February 2022

Published: 24 February 2022

Publisher's Note: MDPI stays neutral with regard to jurisdictional claims in published maps and institutional affiliations.

Copyright: (C) 2022 by the authors. Licensee MDPI, Basel, Switzerland. This article is an open access article distributed under the terms and conditions of the Creative Commons Attribution (CC BY) license (https:// creativecommons.org/licenses/by/ $4.0 /)$.
1 Medicinal Chemistry and Molecular Modeling Lab, Department of Pharmaceutical Chemistry, School of Pharmaceutical Education and Research, Jamia Hamdard, New Delhi 110062, India; zahangir.jh@gmail.com (M.J.A.); javednaim88@rediffmail.com (M.J.N.)

2 Genome Biology Lab, Department of Biosciences, Jamia Millia Islamia, New Delhi 110020, India; ahmad86.delhi@gmail.com (A.P.); rizvi_ma@yahoo.com (M.A.R.)

3 National Institute of Pharmaceutical Education and Research, Guwahati 781101, India; vgmnaidu@gmail.com

4 Department of Pharmaceutical Chemistry, Faculty of Pharmacy, Northern Border University, Rafha 91911, Saudi Arabia; imran.pchem@gmail.com

5 Department of Pharmacy Practice, College of Pharmacy, Al-Maarefa University, Ad Diriyah 13713, Saudi Arabia; mghoneim@mcst.edu.sa

6 Department of Pharmaceutics, College of Pharmacy, King Saud University, Riyadh 11451, Saudi Arabia; salshehri1@ksu.edu.sa (S.A.); fsahmad@ksu.esu.sa (F.S.)

* Correspondence: oalam@jamiahamdard.ac.in

\begin{abstract}
Some (E)-3-(3-(4-(benzyloxy)phenyl)-1-phenyl-1H-pyrazol-4-yl)-1-phenylprop-2-en-1-one conjugates 5a-r were designed; synthesized; characterized by ${ }^{1} \mathrm{H},{ }^{13} \mathrm{C}$ NMR, and ESI-MS; and evaluated for tubulin polymerization inhibitory activity and in vitro cytotoxicity against breast (MCF-7), cervical (SiHa), and prostate (PC-3) cancer cell lines, as well as a normal cell line (HEK-293T). The compounds were also tested to determine their binding modes at the colchicine-binding site of tubulin protein (PDB ID-3E22), for in silico ADME prediction, for bioactivity study, and for PASS prediction studies. Among all the synthesized conjugates, compound 50 exhibited excellent cytotoxicity with an $\mathrm{IC}_{50}$ value of $2.13 \pm 0.80 \mu \mathrm{M}$ (MCF-7), $4.34 \pm 0.98 \mu \mathrm{M}$ (SiHa), and $4.46 \pm 0.53 \mu \mathrm{M}$ (PC-3) against cancer cell lines. The compound did not exhibit significant toxicity to the HEK cells. Results of the in silico prediction revealed that the majority of the conjugates possessed drug-like properties.
\end{abstract}

Keywords: pyrazole conjugate; anticancer; MTT assay; molecular docking; cytotoxicity; tubulin polymerization inhibitors

\section{Introduction}

Cancer is significantly the most common health issue worldwide. It is considered the second most recurrent death-causing factor after cardiovascular disorders [1,2]. It accounts for nearly 10 million deaths in 2020, with most deaths due to lung cancer, followed by colon, liver, stomach, and breast cancer [3]. The World Health Organization (WHO) has projected that by 2030, more than 13 million annual deaths are expected to occur from cancer globally [4]. Currently available chemotherapeutic agents that target cell division and angiogenesis, or induce cancer cell death through different signaling pathways comprise the major treatment options for cancer. While these therapies are effective in treating early-stage cancers, the efficacy against advanced cancers, especially multidrug-resistant cancers, is limited. Furthermore, these classes of drug molecules face numerous restrictions such as greater systemic toxicity and complex synthesis [5]. 
The microtubules are a dynamic polymeric network of two closely related $55 \mathrm{kDa}$ proteins in cells known as $\alpha$ and $\beta$-tubulin dimers [6]. It is responsible for the formation of the mitotic spindle during cell division and the severance of duplicated chromosomes. It also plays a crucial role as an important target for cancer therapy because of its essential role in cell proliferation and angiogenesis [7]. Since rapidly dividing cancer cells are highly dependent on tubulin polymerization/depolymerization, interfering with tubulin dynamics has become an important approach for the development of mitotic inhibitors $[8,9]$. The tubulin inhibitors have been classified based on their binding domains to tubulin viz. microtubule destabilizers (e.g., Combretastatin A-4) [10], colchicine site-binding agents (e.g., colchicine and podophyllotoxin) [11,12], and the vinca site-binding agent (e.g., vinblastine and vincristine) [13]. The microtubule disrupters inhibit tubulin polymerization and consequently interfere with the formation of the necessary mitotic assembly required for cell division. On the other hand, microtubule stabilizers, such as taxanes [14], paclitaxel, docetaxel, and laulimalide, prevent the depolymerization of microtubules [15]. Both agents, which can disrupt as well as stabilize microtubules, have found clinical success as anticancer agents, therefore the compounds that can affect tubulin or microtubule stability may show potential against various cancers. That is why, nowadays, scientists draw attention to the drug discovery of microtubule-targeting agents/inhibitors for anticancer therapy. The trimethoxy/dimethoxy phenyl rings of reported ligands are well-defined pharmacophores that bind to the interface of the $\alpha$-tubulin and $\beta$-tubulin of the colchicinebinding site, which destabilizes the microtubules [16-19]. In the past few years, several chalcone derivatives were found as the most effective tubulin polymerization inhibitors as well as safer anticancer molecules [20]. The three binding sites are present in tubulin as the colchicine-binding site, vinca-binding site, and taxane-binding site. The tubulin polymerization inhibitors are docked into the colchicine-binding site of the tubulin protein. The colchicines always interact and bind with the $\alpha$-tubulin and $\beta$-tubulin interface, which was also established by molecular docking [21] (Figure 1). The colchicine forms hydrogen, bonding with the Cys-241 of the $\beta$ subunit of tubulin.

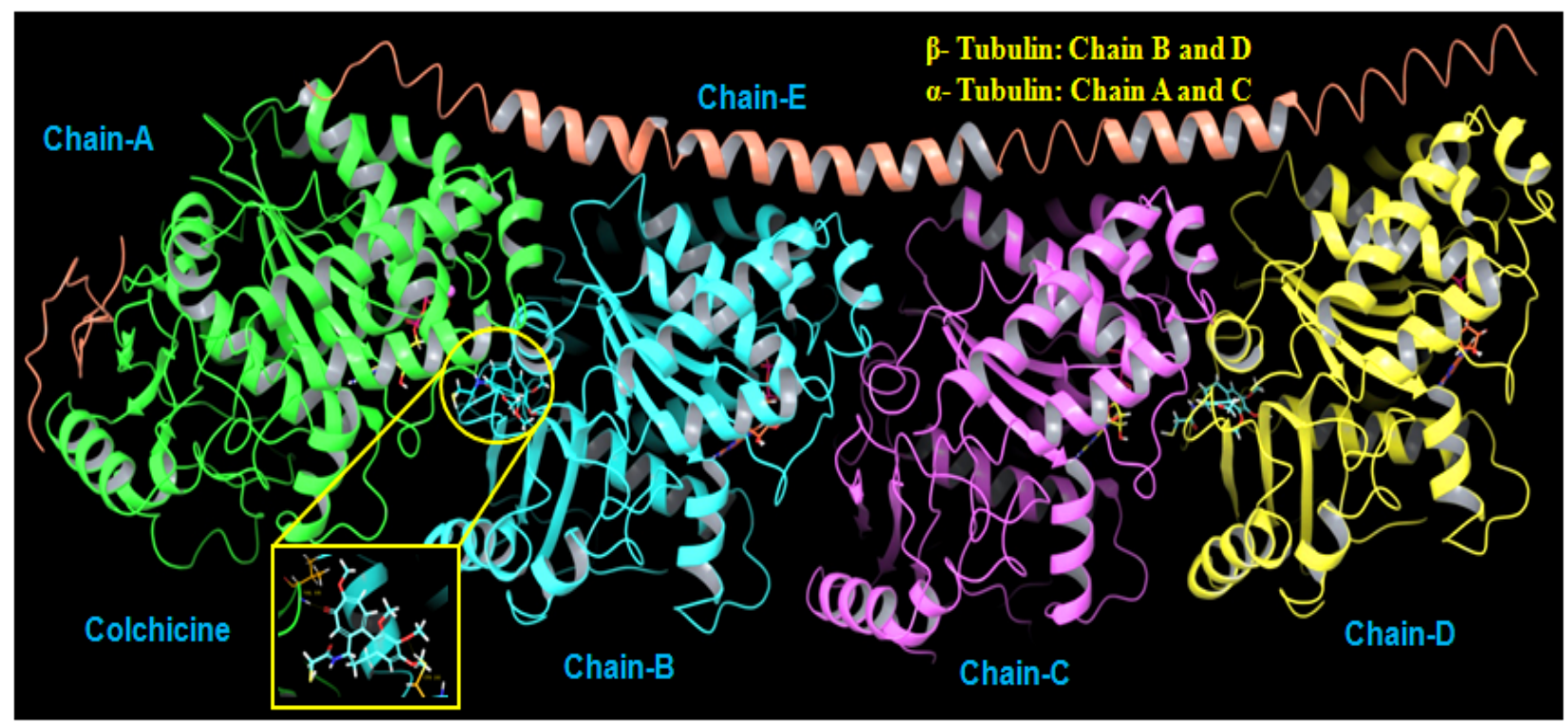

Figure 1. Colchicine-binding site (PDB: 1SA0).

Pyrazole is a significant class of heterocyclic compounds in pharmaceutical chemistry. Many pyrazole-based lead compounds have been evaluated for their biological effects, including anti-inflammatory, antimicrobial, antioxidant, anti-depressant, and antiinfluenza activities [22,23]. Several recent reports suggested that pyrazole derivatives have shown promising anticancer activity, indicating their use in the development of new anticancer agents [24]. Among the anticancer pyrazole moieties, 1,3-diphenyl pyra- 
zole derivatives have been shown as potent and effective cytotoxic agents [25]. Chalcone conjugates have shown wide pharmacological efficacy as well as synthetic applications in pharmaceutical chemistry [26,27]. Presently, colchicine (A), combretastatin A-4 (B) analogs, pyrazole linker chalcone congeners, and the marketed drug nocodazole $(\mathrm{C})$ are the most important tubulin-binding agents that inhibit tubulin depolymerization [28]. In the recently reported literature, Peyrot et al. synthesized (E)-3-(4-(dimethylamino)phenyl)-1(2,5-dimethoxyphenyl)-2-methylprop-2-en-1-one (D, MDL-27048) [29] as anti-mitotic agents with rapid and reversible binding to the colchicine-binding site for inhibiting its assembly to microtubules. Kamal et al. [30] designed and synthesized a novel scaffold (Z)-3-((3phenyl-1H-pyrazol-5-yl)methylene)indolin-2-one (E), which has significant polymerization inhibitory activity. Moreover, various 1,3,4 thiadiazole ring-based cinnamide derivatives tubulin (F) [31] also exhibited significant growth inhibition effects against MCF-7 and A549 cell lines apart from effectively inhibiting tubulin polymerization. Srinivasa and co-workers synthesized a new class of (Z)-1-(1,3-diphenyl-1H-pyrazol-4-yl)-3-(phenylamino)prop-2en-1-one derivatives $(\mathrm{G})$ as an effective anticancer agent with $\mathrm{IC}_{50}$ values ranging from 1.25 to $3.98 \mu \mathrm{M}$ [32]. In addition, Kamal and co-workers synthesized a series of pyrazolelinked arylcinnamides $(\mathrm{H})$ as potential antiproliferative agents with significant tubulin polymerization inhibitory action (Figure 2) [33].

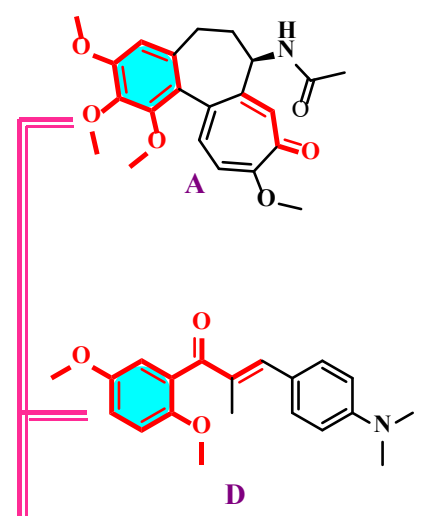

D<smiles>O=C(/C=C/Nc1ccccc1)c1cn(-c2ccccc2)nc1-c1ccccc1</smiles><smiles>COc1ccc(/C=C\c2cc(OC)c(OC)c(OC)c2)cc1O</smiles><smiles></smiles>

E<smiles>CCCc1nc2ccc(C(=O)c3cccs3)cc2[nH]1</smiles>

C<smiles>Cc1ccc(-c2nnc(NC(=O)/C=C/c3ccccc3)s2)cc1</smiles>

F

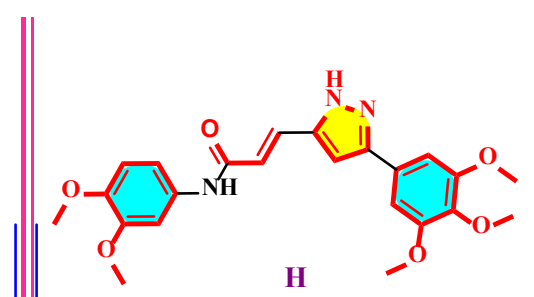

H<smiles>COc1ccc(C(=O)/C=C/c2cn(-c3ccccc3)nc2-c2ccc(OCc3ccccc3)cc2)cc1OC</smiles>

compound (50)

Figure 2. Structures of some potential cytotoxic agents and tubulin polymerization inhibitors: colchicine (A), combretastatin-A4 (B), nocodazole (C), MDL-27048 (D), reported pyrazole-linked conjugates $(\mathbf{E})$, reported chalcone-linked conjugates $(\mathbf{F})$, reported pyrazole-linked chalcone conjugates $(\mathbf{G}, \mathbf{H})$, and novel hybrid compound (5o).

Hybrid chalcone derivatives possess structural similarities to occurring moieties, such as Combretastatin A-4, obtained from the bark of Combretum caffrum [34]. It has 
exhibited cytotoxicity against a broad range of human cancer cell lines by binding at the colchicine-binding site on $\beta$ tubulin with a percentage of inhibition in the range of 28.42-66.40\%. Furthermore, hybrid chalcones linked to other heterocyclic moieties have resulted in enhanced anticancer activity [35]. With this background, the present work was carried out to design and synthesize novel pyrazole-linked hybrid chalcone conjugates, and to evaluate their ability to inhibit tubulin polymerization and consequently prevent cancer growth.

\section{Results and Discussion}

\subsection{Chemistry}

The protocol for the synthesis of analog (5a-r) is described in Scheme 1. Compound 1 was prepared by reacting 4-hydroxyacetophenone and benzyl chloride. It was then reacted with phenylhydrazine (2) to give compound 3, which was further cyclized in the presence of $\mathrm{POCl}_{3}$ and DMF (Vilsmeier Haack reaction) to give 3-(4-(Benzyloxy) phenyl)-1phenyl-1H-pyrazole-4-carbaldehyde (4). Equimolar quantities of compound 4 and various substituted acetophenones underwent Claisen-Schmidt condensation to yield the final pyrazole-chalcone conjugates. All compounds were characterized by FT-IR, ${ }^{1} \mathrm{H}$ NMR, ${ }^{13} \mathrm{C}$ NMR, and mass spectral data. The ${ }^{1} \mathrm{H} \mathrm{NMR},{ }^{13} \mathrm{C} \mathrm{NMR}$, and mass spectra of lead compounds are presented in Figures S1-S14. The ${ }^{1} \mathrm{H}$ NMR spectra of the aldehydic proton in compound 4 appeared as a singlet at $\delta 9.82 \mathrm{ppm}$. The H-6 and H-7 of compound 5a appeared as a doublet at $\delta 7.95$ and $\delta 8.01 \mathrm{ppm}$, respectively, with the coupling constant $(J=15.6-15.7 \mathrm{~Hz})$, which agrees with the trans-configuration of $\alpha, \beta$-unsaturated ketone and the disappearance of the signal corresponding to the $\mathrm{C}-\mathrm{H}$ of aldehyde. Moreover, in the ${ }^{13} \mathrm{C}$ NMR spectrum, the signal for $\mathrm{C}-1$ was in the range of $\delta 127.8-139.6 \mathrm{ppm}$ and the signal for $C-7$ appeared at $\delta 113.1-127.7 \mathrm{ppm}$, while the $\mathrm{C}=\mathrm{O}$ carbon atom appeared at $\delta 186.3-196.1 \mathrm{ppm}$. The IR spectra showed absorption bands at 1755-1675, 1653-1590, and 1590-1512 $\mathrm{cm}^{-1}$, corresponding to the $\mathrm{C}=\mathrm{O}, \mathrm{C}=\mathrm{N}$, and $\mathrm{C}=\mathrm{C}$ functionalities, respectively. Mass spectra showed a molecular ion peak, i.e., $(\mathrm{m} / z)\left[\mathrm{M}^{+}\right]$with a characteristic fragmentation pattern involving the loss of the phenyl group in all cases.

\subsection{Molecular Docking Study}

Molecular docking was performed to establish the binding ability of the newer synthesized compounds to the colchicine-binding site of tubulin (PDB code: 3E22). The docking scores of the compounds (5a-r) and co-crystal ligand colchicine are given in Table 1 . The protein backbone of tubulin is depicted in purple and yellow colors for $\alpha$ and $\beta$ chains, respectively. The favorable hydrogen bonding interactions are shown with yellow dashed lines and the amino acid residues that interact with the compounds are represented as purple and yellow tubes. The standard compounds were docked as co-crystal ligands at the colchicine-binding site of tubulin. Docking studies revealed that eighteen newer compounds (5a-r) exhibited a higher docking score than that of the co-crystal ligand, suggesting that the synthesized molecules have better interaction and better accommodation within the binding site. The different binding sites of tubulin protein complexes with 50 viz. GTP, $\mathrm{Mg}^{+2}$, and GDP are shown in Figure 3. The 3D docked images of compound 50 and 5 p complexes with tubulin are represented in Figure 4. The most promising compound 5o could fit well into the colchicine-binding site of the tubulin, making five hydrogen bond interactions with the most important active site residues ASN $249\left(\mathrm{O}_{2 . . . H_{2} \mathrm{~N}, 3.53 \AA} \mathrm{A}, \beta-\right)$, ALA $250\left(\mathrm{O} \ldots . . \mathrm{H}_{2} \mathrm{~N}, 3.70 \AA\right)$ and LYS $254\left(\mathrm{O} \ldots . . \mathrm{H}_{3} \mathrm{~N}^{+}, 3.30 \AA\right)$, SER $178(\mathrm{O} \ldots . . \mathrm{HN}, 3.65 \AA)$, and TYR $224\left(\mathrm{O} . . . . \mathrm{HO}, 3.23 \AA\right.$ ) pi-cation LYS 352 (pyrazole.... $\mathrm{H}_{3} \mathrm{~N}^{+}, 6.17 \AA$, and phenyl.... $\mathrm{H}_{3} \mathrm{~N}^{+}, 6.26$ $\AA$ ), as depicted in Figure 5a. The methoxy group of the 3,4-dimethoxy aryl moiety exhibited interaction with the side chain of SER $178\left(\mathrm{O} \ldots . . \mathrm{H}_{2} \mathrm{~N}, 1.93 \AA\right)$ and TYR $224\left(\mathrm{O} \ldots . . \mathrm{H}_{2} \mathrm{~N}, 1.93 \AA\right)$ in a similar manner as the co-crystal ligand colchicine. Introduction of a methoxy group at positions two and four of the aromatic ring of compounds leads to a slight decrease in the inhibitory activity primarily due to the changing of the orientation of the 2,4-dimethoxy group in the binding site, as observed for compound $5 \mathrm{p}$. The carbonyl group of $5 \mathrm{p}$ also 
showed hydrogen bond interaction with the side chain of ASN $249\left(\mathrm{O} \ldots . . \mathrm{H}_{2} \mathrm{~N}, 2.87 \AA\right)$, ALA $250\left(\mathrm{O} \ldots . . \mathrm{H}_{2} \mathrm{~N}, 2.91 \AA\right)$, and LYS $254\left(\mathrm{O} \ldots . . \mathrm{H}_{3} \mathrm{~N}^{+}, 3.10 \AA\right)$.
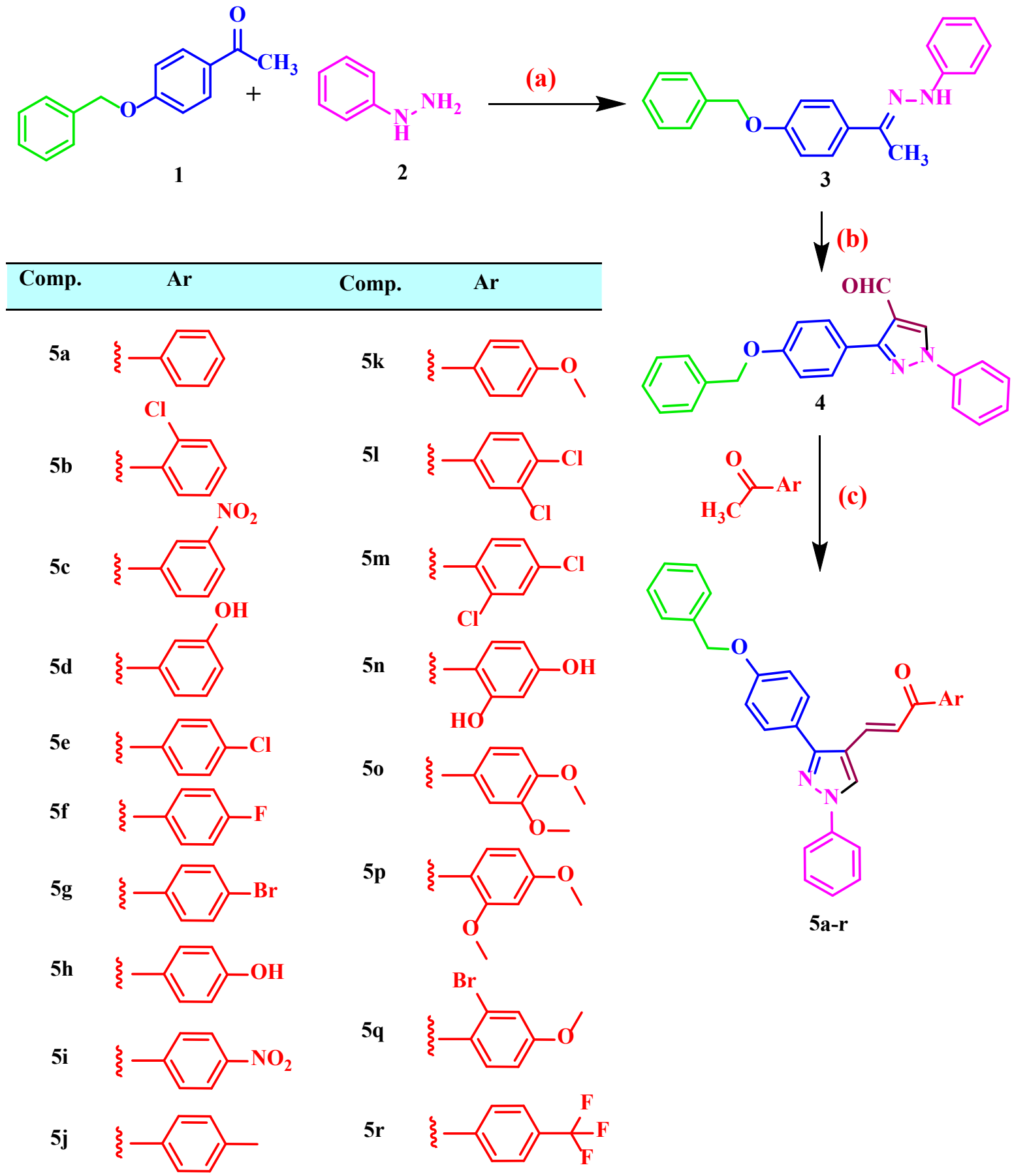

(c)
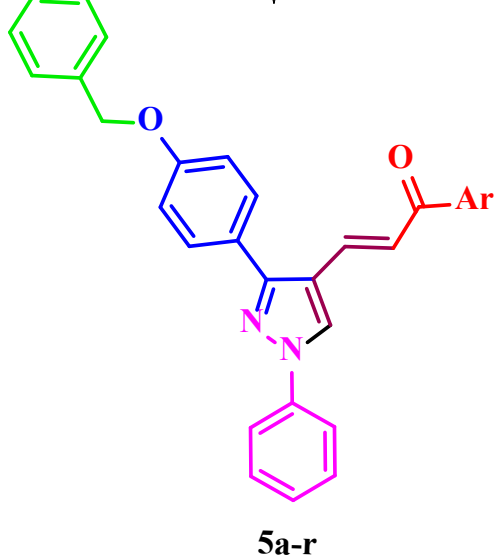

Scheme 1. General synthesis of (E)-3-(3-(4-(benzyloxy)phenyl)-1-phenyl-1H-pyrazol-4-yl)-1phenylprop-2-en-1-one derivatives (5a-r). Reagents and conditions: (a) absolute ethanol and glacial acetic acid, 50-60 ${ }^{\circ} \mathrm{C}$, refluxed for 6-8 h; (b) DMF and $\mathrm{POCl}_{3}$, heated for $2 \mathrm{~h}$ on steam bath; and (c) absolute ethanol, $40 \% \mathrm{NaOH}$, reflux. 
Table 1. Docking score and anti-tubulin activity of E-3-(3-(4-(benzyloxy) phenyl)-1-phenyl- $1 H$ pyrazol-4-yl)-1-phenylprop-2-en-1-one analogs (5a-r).

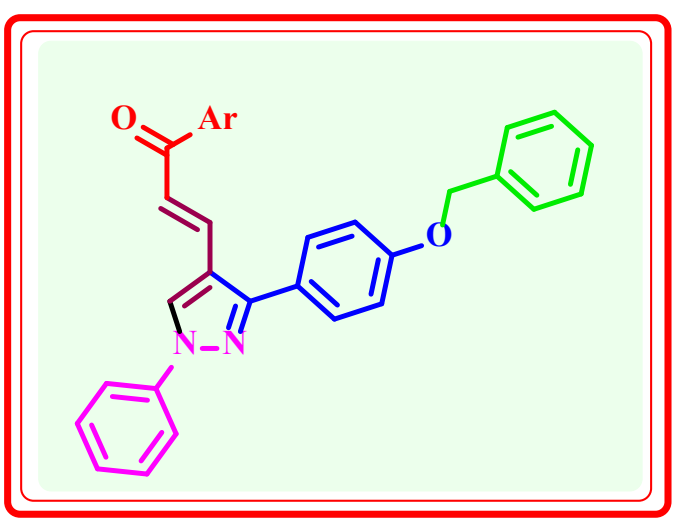

\begin{tabular}{|c|c|c|c|c|}
\hline Comp. & Ar & Docking Score & $\begin{array}{l}\% \text { Inhibition of Tubulin } \\
\text { Polymerization at } 10 \mu \mathrm{M}^{\mathrm{b}}\end{array}$ & $\begin{array}{c}\text { Inhibition of Tubulin } \\
\text { Polymerization } \\
\mathrm{IC}_{50}(\mu \mathrm{M})^{\mathrm{a}}\end{array}$ \\
\hline $5 a$ & & -5.994 & $\mathrm{Nd}$ & $\mathrm{Nd}$ \\
\hline $5 b$ & & -5.934 & $\mathrm{Nd}$ & $\mathrm{Nd}$ \\
\hline $5 c$ & & -5.873 & $\mathrm{Nd}$ & $\mathrm{Nd}$ \\
\hline $5 d$ & & -6.967 & 49.78 & $1.65 \pm 0.06$ \\
\hline $5 e$ & & -6.937 & 48.44 & $1.58 \pm 0.04$ \\
\hline $5 f$ & & -6.241 & $\mathrm{Nd}$ & $\mathrm{Nd}$ \\
\hline $5 g$ & & -5.531 & $\mathrm{Nd}$ & $\mathrm{Nd}$ \\
\hline $5 \mathrm{~h}$ & & -5.752 & $\mathrm{Nd}$ & $\mathrm{Nd}$ \\
\hline $5 i$ & & -6.249 & 28.42 & $3.58 \pm 0.83$ \\
\hline $5 \mathbf{j}$ & & -5.952 & $\mathrm{Nd}$ & $\mathrm{Nd}$ \\
\hline $5 k$ & & -6.432 & 32.79 & $3.03 \pm 0.44$ \\
\hline 51 & & -7.072 & 55.17 & $1.73 \pm 0.04$ \\
\hline $5 \mathrm{~m}$ & & -6.664 & 33.76 & $2.97 \pm 0.03$ \\
\hline $5 n$ & & -6.751 & 47.56 & $2.73 \pm 0.07$ \\
\hline
\end{tabular}


Table 1. Cont.

\begin{tabular}{|c|c|c|c|c|}
\hline Comp. & Ar & Docking Score & $\begin{array}{l}\% \text { Inhibition of Tubulin } \\
\text { Polymerization at } 10 \mu \mathrm{M}^{\mathrm{b}}\end{array}$ & $\begin{array}{l}\text { Inhibition of Tubulin } \\
\text { Polymerization } \\
\text { IC }_{50}(\mu \mathrm{M})^{a}\end{array}$ \\
\hline 50 & & -7.002 & 66.40 & $1.15 \pm 0.06$ \\
\hline $5 p$ & & -7.277 & 51.11 & $1.93 \pm 0.03$ \\
\hline $5 q$ & & -6.111 & $\mathrm{Nd}$ & $\mathrm{Nd}$ \\
\hline $5 r$ & & -6.367 & 31.50 & $2.34 \pm 0.63$ \\
\hline $\begin{array}{l}\text { Co-crystal- } \\
\text { colchicine }\end{array}$ & - & -7.059 & 一 & 一- \\
\hline Control & 一 & - & 0.0 & 0.0 \\
\hline Paclitaxel $(3 \mu \mathrm{M})$ & - & - & -25.73 & $0.53 \pm 0.12$ \\
\hline $\begin{array}{l}\text { Combretastatin } \\
\text { A-4 }(6 \mu \mathrm{M})\end{array}$ & 一 & - & 72.30 & $1.46 \pm 0.05$ \\
\hline Vincristine $(3 \mu \mathrm{M})$ & - & - & 75.45 & $1.54 \pm 0.54$ \\
\hline
\end{tabular}

a Half-maximal inhibitory concentration: compound concentration required to inhibit tubulin polymerization by $50 \%$; data are the mean $\pm \mathrm{SD}$ of $n=3$ independent experiments performed in triplicates. ${ }^{\mathrm{b}}$ Inhibition of tubulin polymerization at $10 \mu \mathrm{M}$ (final volume $=10 \mathrm{~mL}$ ); compounds were pre-incubated with tubulin at a final concentration of $10 \mu \mathrm{M}$.

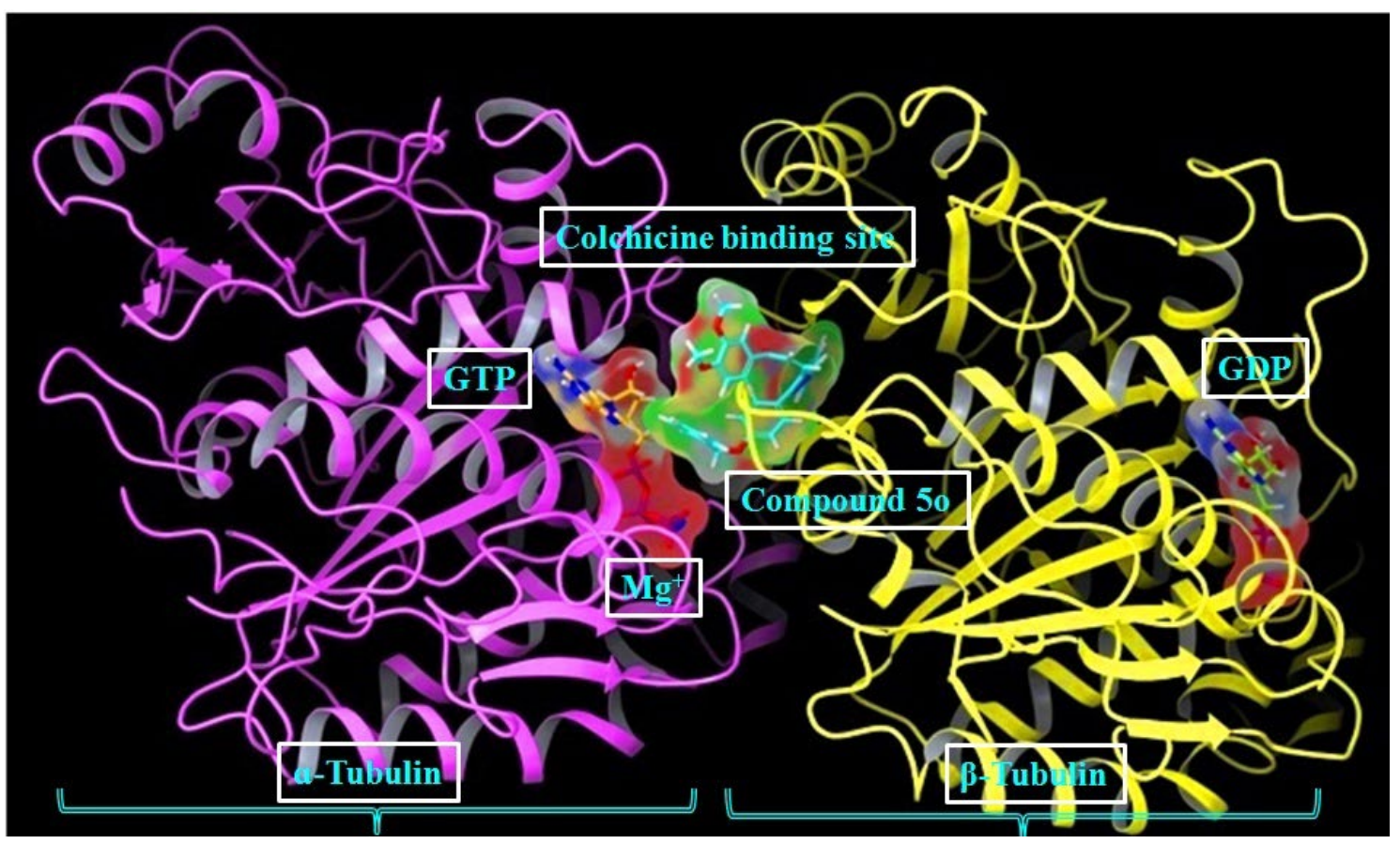

Figure 3. Different binding sites of tubulin protein complexes with 50 (turquoise-color stick model), GTP, $\mathrm{Mg}^{+2}$, and GDP. The $\alpha$-chain is represented in purple color and the $\beta$-chain is represented in yellow color. 

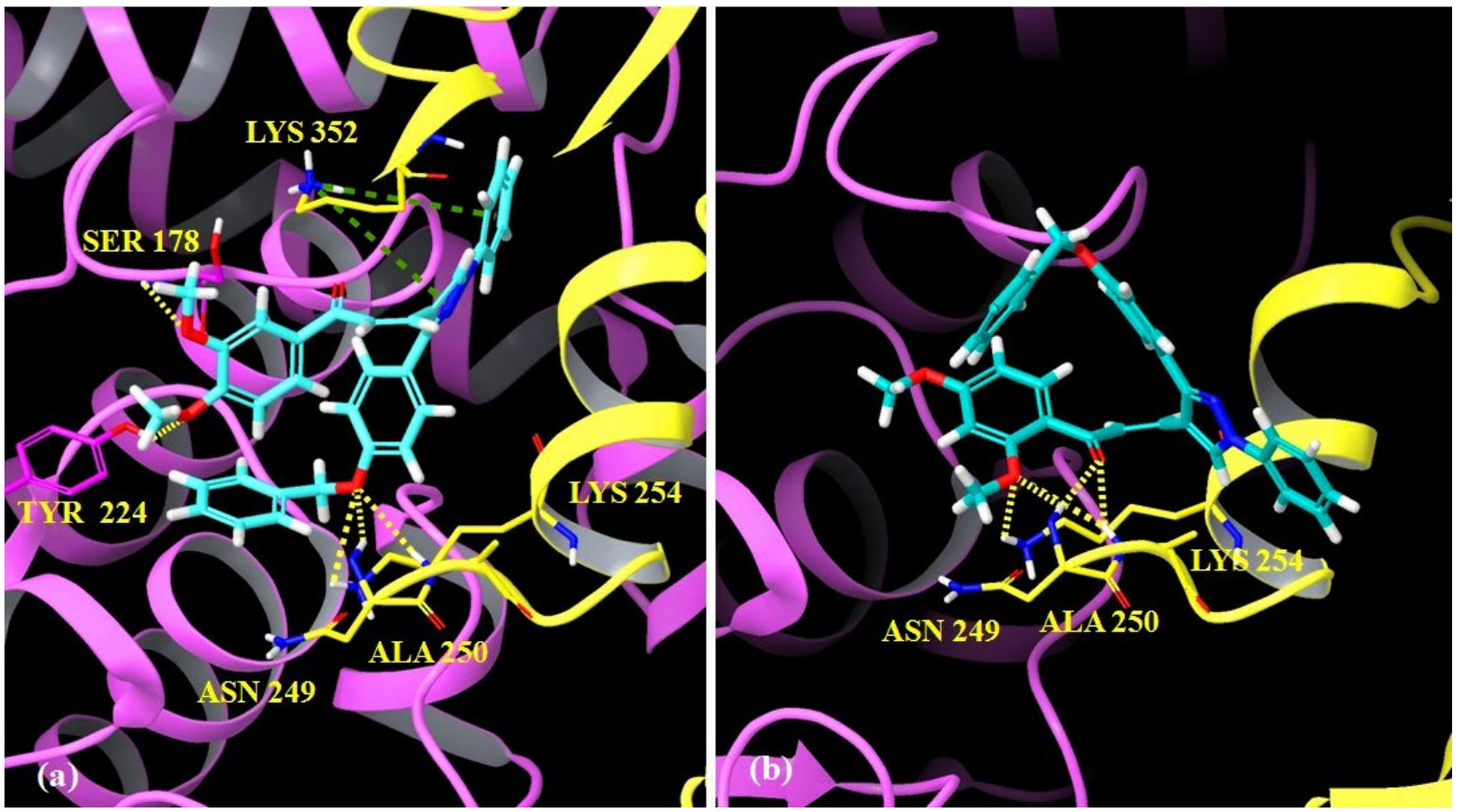

Figure 4. (a) Docked pose of compound 5o (turquoise color) showing hydrogen bond interaction (yellow dashed lines) with ASN 249, ALA 250, LYS 254, SER 178, and TYR 224; pi-cation interaction with LYS 352 in the colchicine-binding site of tubulin. (b) Docked pose of compound 5p (turquoise color) showing hydrogen bond interaction (yellow dashed lines) with ASN 249, ALA 250, and LYS 254 in the colchicine-binding site of tubulin. The $\alpha$-chain is represented in a purple color cartoon and the $\beta$-chain is represented in a yellow color cartoon model.
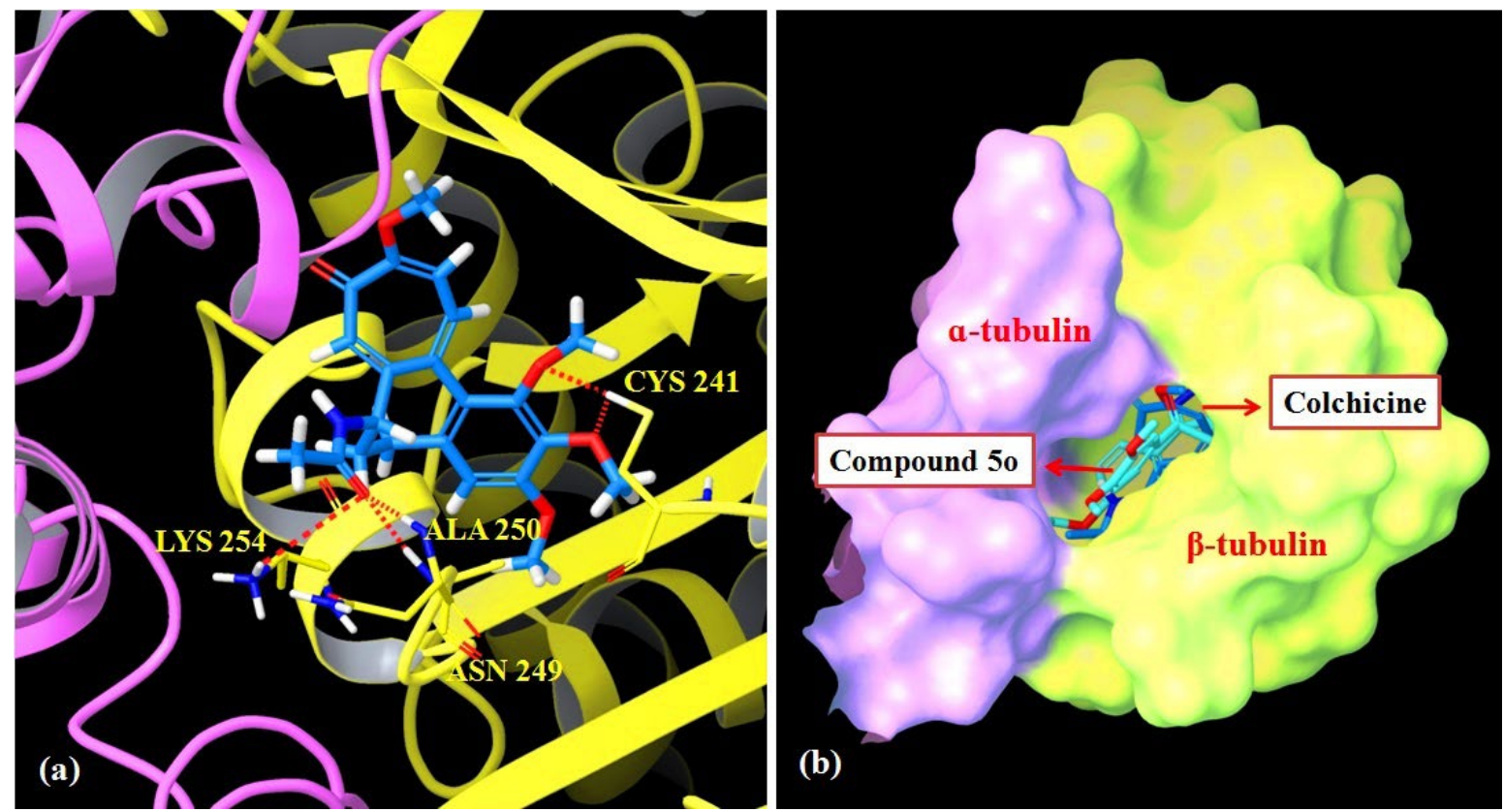

Figure 5. (a) Docked pose of colchicine (blue color) showing hydrogen bond interaction (red dashed lines) with ASN 249, ALA 250, LYS 254, and CYS 241 in the colchicine-binding site of tubulin. The $\alpha$-chain is represented in a purple color cartoon and the $\beta$-chain is represented in a yellow color cartoon model. (b) Receptor surface of superimposing docked pose of compound 5o (turquoise-color stick model) with colchicine (blue-color stick model) at colchicine-binding site of tubulin. The $\alpha$-chain is represented in the purple color surface and the $\beta$-chain is represented in the yellow color surface. 
The present study showed that the presence of methoxy groups at positions three and four of the aromatic ring of the ligand has a significant inhibitory effect on the tubulin polymerization at positions two and four. The positions of the methoxy $\left(\mathrm{OCH}_{3}\right)$ groups in these two (5o and 5p) compounds showed slight differences in the in silico as well as in vitro studies. This could be due to the difference in the position of the substituents present in the aryl rings. These observations also provide a possible explanation as to why the 3,4-dimethoxy derivative $\mathbf{5 o}$ is the only compound from the series which shows high affinity as well as a high docking score. The docked compound 50 was superimposed with co-crystal ligand colchicine and its binding pattern was then compared (Figure 5a). The co-crystal ligand colchicine formed four hydrogen bond interactions with the most important active site residues ASN $249\left(\mathrm{O} \ldots . . \mathrm{H}_{2} \mathrm{~N}, 1.76 \AA\right)$, ALA $250\left(\mathrm{O} \ldots . . \mathrm{H}_{2} \mathrm{~N}, 1.95 \AA\right)$, LYS $254\left(\mathrm{O} \ldots . . \mathrm{H}_{3} \mathrm{~N}^{+}, 3.61 \AA\right)$, and CYS 241 (O....HS, $2.40 \AA$ and $\left.2.61 \AA\right)$. The receptor surface of the docked conformer 50 complex with tubulin is presented in Figure $5 \mathrm{~b}$. The $\mathrm{dG}$ binding energy of the compounds was found in the range of -48.34 to $-91.43 \mathrm{Kcal} / \mathrm{mol}$ for the receptor sites (Table 1). All compounds displayed a higher binding free energy (dG bond) for tubulin, which indicates that the compounds may have higher affinity and stability for the tubulin protein. To validate the molecular docking results, the synthesized compounds with higher dock scores were screened by the in vitro tubulin inhibitory assay. The outcome of molecular docking studies, along with the biological activity, revealed that compound 50 was the most potent inhibitor.

\subsection{Pharmacological Activities}

\subsubsection{In Vitro Cytotoxicity Activity}

The resultant compounds were tested for their in vitro cytotoxic activity by MTT assay against breast (MCF-7), cervical (SiHa), and prostate (PC-3) cancer cell lines, and the human embryonic kidney cell line (HEK) [36]. The relative absorbance of the treated versus control (untreated) cells was used in determining the percentage viability and the $\mathrm{IC}_{50}$ value of Combretastatin A4 (CA4), which was used as the standard. $\mathrm{IC}_{50}$ values of various compounds in the MTT assay are presented in Table 2. Almost all synthesized conjugates were selectively cytotoxic against breast MCF-7 cancerous cells. Moreover, compounds 5d, 5o, and 5p displayed pronounced growth inhibition on MCF-7 cells with $\mathrm{IC}_{50}$ values in the range of $2.13-4.10 \mu \mathrm{M}$, which were equivalent or better than the standard CA-4 (4.12-5.23 $\mu \mathrm{M})$. The effective growth inhibitory activity was exhibited by compound 5 o $\left(\mathrm{IC}_{50}-2.13 \pm 0.80 \mu \mathrm{M}\right)$, followed by the compounds $5 \mathrm{p}\left(\mathrm{IC}_{50} 3.45 \pm 1.28 \mu \mathrm{M}\right)$ and $5 \mathrm{~d}$ $\left(\mathrm{IC}_{50} 4.10 \pm 1.12 \mu \mathrm{M}\right)$ against MCF-7 cancer cells. The other two cancer cell lines, SiHa and PC-3, also showed maximum sensitivity towards these two compounds with $\mathrm{IC}_{50}$ values of less than $6.52 \mu \mathrm{M}$. Moreover, compound $5 \mathrm{n}$ showed higher potency against SiHa cells with an $\mathrm{IC}_{50}$ value of $3.60 \pm 0.45 \mu \mathrm{M}$, while compound $\mathbf{5 d}$ revealed selective potency against PC-3 cells with an $\mathrm{IC}_{50}$ value of $2.97 \pm 0.88 \mu \mathrm{M}$. All compounds were further tested on non-cancerous HEK cells, where most compounds did not show any significant cytotoxicity $\left(\mathrm{IC}_{50}>50 \mu \mathrm{M}\right)$. The compounds $\mathbf{5 r}$ and $\mathbf{5 i}$ displayed moderate growth inhibition on $\mathrm{HEK}$ cells with $\mathrm{IC}_{50}$ values of 38.30 and $45.23 \mu \mathrm{M}$, respectively. These results expressed the selectivity of 1,3-diphenyl- $1 H$ pyrazole hybrids towards cancer cells compared to normal HEK cells. Therefore, the high cytotoxicity of the synthesized anticancer agents and their selectivity towards cancer cells were found to be characteristic factors. Subsequently, SAR studies were done by investigating the effect of substituents on cytotoxic activity. It has been shown that compounds with strong electron-donating groups on the aromatic ring $\left(\mathrm{OH}>\mathrm{OCH}_{3}\right)$ exhibited potent cytotoxic activity. Furthermore, the compounds with electron-donating groups such as 3,4-dimethoxy substitution and 2,4-dimethoxy (5o and 5p) exhibited higher potency than para-Methoxy substitutions (5k). Furthermore, compounds with electron-withdrawing groups such as para-chloro, paranitro, 3,4-dichloro, and trifluoromethyl substitutions (5e, 5i, 51, and $\mathbf{5 r}$ ) on the phenyl rings displayed good cytotoxic strength $\left(\mathrm{Cl}>\mathrm{NO}_{2}>\mathrm{CF}_{3}\right)$ on cancerous cells (Figure 6). The majority of the compounds in this scheme exhibited moderate selectivity index values. 
Moreover, the pharmacological efficacy of the synthesized entities $5 d, 5 n, 50$, and 5 p has created a scope to explore their profound efficacy at the cellular level and particularly using the mechanism proposed for cytotoxic effects.

Table 2. In vitro cytotoxic effect $\left(\mathrm{IC}_{50}, \mu \mathrm{M}\right)$ of the E-3-(3-(4-(benzyloxy) phenyl)-1-phenyl-1H-pyrazol4-yl)-1-phenylprop-2-en-1-one against a panel of human cancer and normal cell lines.

\begin{tabular}{ccccc}
\hline \multirow{2}{*}{ Comp. } & \multicolumn{4}{c}{ Cell Line $\left(\mathbf{I C}_{\mathbf{5 0}}\right)^{\mathbf{a}}$} \\
\cline { 2 - 5 } & $\mathbf{M C F - 7}^{\mathbf{b}}$ & $\mathbf{S i H a}^{\mathbf{c}}$ & $\mathbf{P C 3}^{\mathbf{d}}$ & HEK-293 $^{\mathbf{e}}$ \\
\hline $\mathbf{5 d}$ & $4.10 \pm 1.12$ & $4.85 \pm 0.89$ & $2.97 \pm 0.88$ & $>50$ \\
$\mathbf{5 e}$ & $11.50 \pm 1.62$ & $12.3 \pm 1.32$ & $9.68 \pm 1.42$ & $>50$ \\
$\mathbf{5 i}$ & $42.70 \pm 0.34$ & $34.53 \pm 0.90$ & $13.14 \pm 1.6$ & $45.23 \pm 2.60$ \\
$\mathbf{5} \mathbf{k}$ & $7.23 \pm 0.74$ & $5.65 \pm 0.71$ & $5.45 \pm 0.94$ & $>50$ \\
$\mathbf{5} \mathbf{5}$ & $8.23 \pm 1.45$ & $11.70 \pm 2.83$ & $5.84 \pm 1.65$ & $>50$ \\
$\mathbf{5}$ & $17.14 \pm 2.25$ & $6.46 \pm 1.52$ & $11.22 \pm 1.44$ & $>50$ \\
$\mathbf{5} \mathbf{5}$ & $6.98 \pm 1.12$ & $3.60 \pm 0.45$ & $3.56 \pm 0.63$ & $>50$ \\
$\mathbf{5} \mathbf{p}$ & $2.13 \pm 0.80$ & $4.34 \pm 0.98$ & $4.46 \pm 0.53$ & $>50$ \\
$\mathbf{5 r}$ & $3.45 \pm 1.28$ & $4.98 \pm 0.54$ & $6.52 \pm 1.23$ & $>50$ \\
$\mathbf{C A - 4}$ & $14.82 \pm 2.76$ & $>50$ & $>50$ & $38.3 \pm 1.72$ \\
& $4.12 \pm 0.38$ & $5.23 \pm 0.85$ & $3.86 \pm 0.39$ & $19.25 \pm 1.65$
\end{tabular}

Cell lines were treated with different concentrations of compounds for $48 \mathrm{~h}$ as described under experimental protocol. Cell viability was measured by employing MTT assay. ${ }^{\mathrm{a}} \mathrm{IC}_{50}$ values are the concentrations causing $50 \%$ inhibition of cancer cell growth $(\mu \mathrm{M})$. Data represent the mean values \pm standard deviation of three independent experiments performed in triplicates. ${ }^{\mathrm{b}}$ Breast cancer, ${ }^{\mathrm{c}}$ cervical cancer, ${ }^{\mathrm{d}}$ prostate cancer cell line, and ${ }^{\mathrm{e}}$ human normal cell line CA-4: Combretastatin A-4.

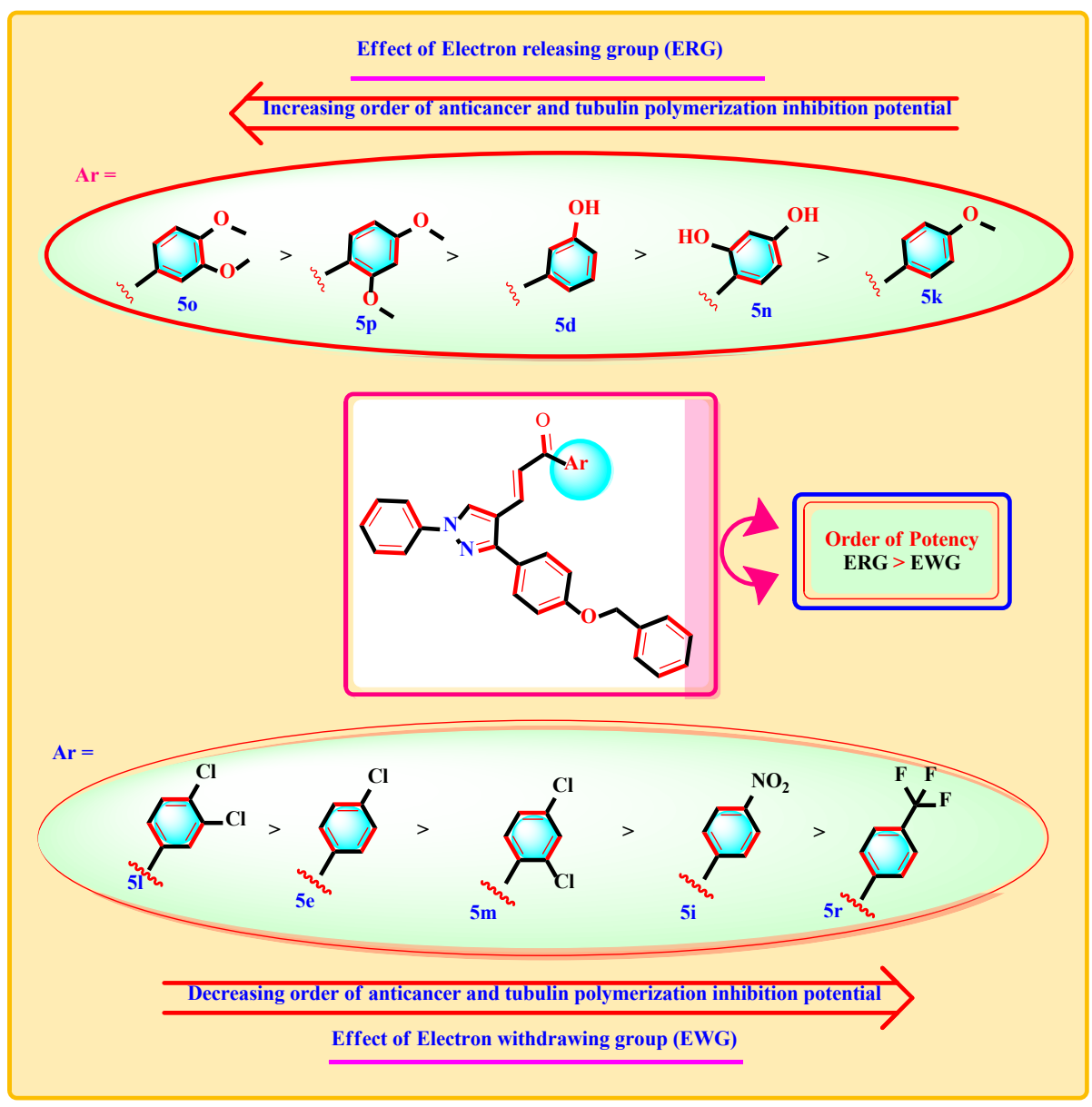

Figure 6. SAR of titled compounds. 


\subsubsection{Tubulin Polymerization Assay}

The $\alpha$ and $\beta$ tubulin subunits are recognized by heterodimers and self-assemble into a stable microtubule in a time-dependent manner. Assessment of the inhibitory effect of new pyrazolic chalcone conjugates on tubulin polymerization was also carried out. The progression of tubulin polymerization was thus examined by monitoring the increase in the fluorescence intensity at $450 \mathrm{~nm}$ (excitation wavelength of $360 \mathrm{~nm}$ ) in a 384-plate for $1 \mathrm{~h}$ at $37{ }^{\circ} \mathrm{C}$ with and without the conjugate at $10 \mu \mathrm{M}$ concentration. CA-4 $(6 \mu \mathrm{M})$ and Vincristine $(3 \mu \mathrm{M})$ were used as the positive control, whereas paclitaxel $(3 \mu \mathrm{M})$ was used as the negative control. The effect of lead conjugates on tubulin polymerization is presented in Figure 5. The compounds 5d, 5e, 5i, 5k, 51, 5m, 5n, 5o, 5p, and 5r exhibited $28.42-66.40 \%$ inhibition on tubulin polymerization (Figure 7). Among these compounds, 5o, 51, and 5 p showed significant inhibition of tubulin polymerization with $\mathrm{IC}_{50}$ values of $1.15,1.65$, and $1.95 \mu \mathrm{M}$, respectively, as compared with $1.46 \mu \mathrm{M}$ for Combretastatin A-4, as shown in Table 1. In general, these outcomes imply that the lead molecules 5o, 51, and 5 p possess a potent inhibitory effect on microtubule assembly in vitro.

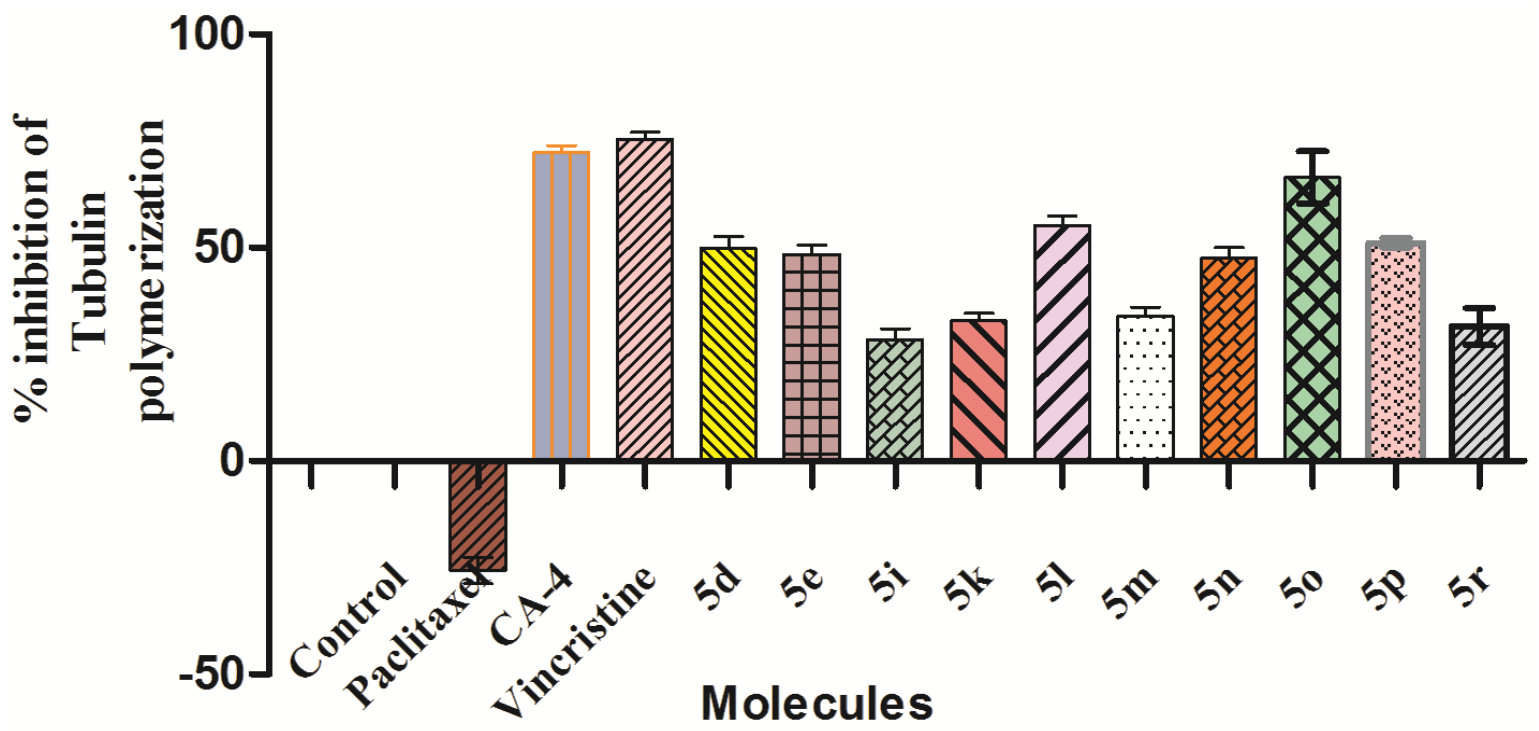

Figure 7. Effect of conjugates on in vitro tubulin polymerization. Values indicated are the mean $\pm S D$ of two different experiments performed in triplicates.

\subsection{In Silico Computational Studies}

Physicochemical properties of lead compounds are important for their development as anticancer agents with an inhibitory effect on tubulin polymerization agents. Improved lipophilicity with reduced water solubility is an essential factor. Different online software are available for the computation of these factors, such as the Molinspiration property calculation toolkit, Osiris Property explorer, PASS prediction, etc. The drug-like characters, such as water solubility ( $\log S)$, the number of rotatable bonds (NROTB), hydrophobicity $(\operatorname{cog} \mathrm{P})$, molecular weight (MW), and the drug-like score of Lipinski's rule of five [37-39], calculated for the lead compounds (5a-r) are represented in Table 3. Most of the synthesized compounds showed an acceptable range of solubility ( $\log S)$, which is less than $(-4.6)$. The synthesized lead with a $\operatorname{cog} \mathrm{P}$-value $<5$ is regarded as the compound with a better drug-likeness profile $[40,41]$. Most of the compounds were found to have a clogP-value of $<5$, which indicated their potential for oral administration. Parameters such as the TPSA (topological polar surface area) of new pyrazole derivatives (5a-r) were found to be within the acceptable range of 39.08-108.08 $\mathrm{A}^{\circ}$. The Molinspiration property calculation toolkit used for calculating the drug-likeness properties recommends that derivatives with negative or zero values should not be regarded as a drug-like candidates. However, all synthesized compounds, except $\mathbf{5} \mathbf{c}$ and $\mathbf{5 i}$, were found to have scores $>0$, as shown in 
Table 3. The predicted toxicity risks of all the synthesized derivatives were envisaged by Osiris Property Explorer and are given in Table 3. The compounds, except for 5c, 5i, and $5 \mathbf{j}$, were found to be non-mutagenic and non-carcinogenic. PASS prediction was performed for the synthesized compounds to omit the compounds with a probability of activity $(\mathrm{Pa})<0.400[42,43]$. The remaining compounds were selected for evaluation based on the net probability of activity over inactivity (Pa-Pi), being more than 0.400 (Table 3).

Table 3. In silico physicochemical properties for oral bioavailability and bioactivity of the test compounds using computational predictive software.

\begin{tabular}{|c|c|c|c|c|c|c|c|c|c|c|c|c|}
\hline \multirow[t]{2}{*}{ Comp. } & \multicolumn{2}{|c|}{$\begin{array}{c}\text { Cancer } \\
\text { Treatment }\end{array}$} & \multirow[t]{2}{*}{ cLogP } & \multirow[t]{2}{*}{ cLogS } & \multirow{2}{*}{$n$ OHNH } & \multirow{2}{*}{$n \mathrm{ON}$} & \multirow{2}{*}{ MW } & \multirow{2}{*}{$\begin{array}{c}\text { Rotatable } \\
\text { Bonds }\end{array}$} & \multirow{2}{*}{$\begin{array}{c}\text { Drug } \\
\text { Likeness }\end{array}$} & \multirow{2}{*}{$\begin{array}{l}\text { Drug } \\
\text { Score }\end{array}$} & \multirow{2}{*}{ TPSA } & \multirow[t]{2}{*}{ Toxicity } \\
\hline & $\mathrm{Pa}$ & Pa-Pi & & & & & & & & & & \\
\hline $5 a$ & 0.65 & 0.64 & 4.59 & -4.60 & 0 & 4 & 456.18 & 8 & 0.97 & 0.34 & 61.80 & $\mathrm{NM}, \mathrm{NC}$ \\
\hline $5 b$ & 0.40 & 0.30 & 3.20 & -2.23 & 1 & 4 & 491.88 & 8 & 1.23 & 0.24 & 63.08 & NM. NC \\
\hline $5 c$ & 0.25 & 0.08 & 4.20 & -3.42 & 1 & 4 & 501.17 & 8 & -2.34 & 0.26 & 39.08 & SR \\
\hline $5 d$ & 0.43 & 0.34 & 4.34 & -3.36 & 0 & 4 & 472.18 & 8 & 3.45 & 0.35 & 65.08 & $\mathrm{NM}, \mathrm{NC}$ \\
\hline $5 e$ & 0.40 & 0.29 & 4.80 & -2.07 & 1 & 4 & 491.88 & 8 & 4.62 & 0.05 & 68.08 & $\mathrm{NM}, \mathrm{NC}$ \\
\hline $5 f$ & 0.37 & 0.25 & 3.40 & -4.34 & 0 & 4 & 477.70 & 8 & 2.82 & 0.36 & 63.60 & $\mathrm{NM}, \mathrm{NC}$ \\
\hline $5 g$ & 0.47 & 0.46 & 3.60 & -3.45 & 0 & 4 & 535.09 & 8 & 1.24 & 0.32 & 70.08 & $\mathrm{NM}, \mathrm{NC}$ \\
\hline $5 \mathrm{~h}$ & 0.43 & 0.42 & 4.56 & -2.67 & 1 & 4 & 472.18 & 8 & 2.87 & 0.23 & 62.07 & $\mathrm{NM}, \mathrm{NC}$ \\
\hline $5 i$ & 0.35 & 0.23 & 4.90 & -3.60 & 1 & 4 & 501.17 & 8 & -2.24 & 0.25 & 80.08 & SM \\
\hline $5 \mathbf{j}$ & 0.49 & 0.493 & 4.90 & -3.78 & 1 & 4 & 471.20 & 8 & 1.37 & 0.11 & 102.30 & SM \\
\hline $5 \mathrm{k}$ & 0.44 & 0.36 & 2.34 & -3.56 & 0 & 10 & 487.19 & 10 & -1.92 & 0.34 & 87.00 & $\mathrm{NM}, \mathrm{NC}$ \\
\hline 51 & 0.43 & 0.42 & 2.23 & -4.02 & 1 & 7 & 524.11 & 9 & 3.45 & 0.25 & 62.90 & $\mathrm{NM}, \mathrm{NC}$ \\
\hline $5 \mathrm{~m}$ & 0.23 & 0.22 & 4.25 & -3.35 & 2 & 5 & 524.11 & 8 & 2.64 & 0.15 & 59.31 & $\mathrm{NM}, \mathrm{NC}$ \\
\hline $5 n$ & 0.49 & 0.41 & 3.60 & -2.54 & 1 & 5 & 488.17 & 9 & -1.56 & 0.56 & 63.31 & $\mathrm{NM}, \mathrm{NC}$ \\
\hline 50 & 0.47 & 0.40 & 3.45 & -2.63 & 1 & 6 & 516.20 & 10 & 1.67 & 0.34 & 63.56 & $\mathrm{NM}, \mathrm{NC}$ \\
\hline $5 p$ & 0.48 & 0.41 & 2.50 & -2.67 & 1 & 4 & 516.20 & 8 & 2.12 & 0.27 & 63.34 & $\mathrm{NM}, \mathrm{NC}$ \\
\hline $5 q$ & 0.29 & 0.13 & 5.20 & -3.24 & 3 & 7 & 525.17 & 9 & 3.44 & 0.48 & 80.20 & $\mathrm{NM}, \mathrm{NC}$ \\
\hline $5 r$ & 0.31 & 0.16 & 4.50 & -3.48 & 3 & 7 & 554.17 & 9 & 2.65 & 0.65 & 75.23 & $\mathrm{NM}, \mathrm{NC}$ \\
\hline
\end{tabular}

Pa: probability of being active; Pi: the probability of being inactive; cLogP: lipophilicity; cLogS: water solubility; $n$ OHNH: number of hydrogen bond donors; $n$ ON: number of hydrogen bond acceptors; MW: molecular weight; TPSA; topological polar surface area; NM: non-mutagenic; NC: non-carcinogenic; SM: slightly mutagenic; and SR: slightly reproducible.

\section{Materials and Methods}

\subsection{General Chemistry}

The chemicals and reagents employed were of LR grade and procured from Sigma Aldrich (Mumbai, India), E. Merck (Mumbai, India), S.D. Fine Chemicals Ltd. (Mumbai, India), and Qualigens (New Delhi, India). Thin-layer chromatography (TLC) was carried out to observe the advancement of the reactions using benzene and acetone $(80: 20, v / v)$, as well as toluene/ethyl acetate/formic acid (50:40:10, $v / v / v)$ as a solvent system, and spots were traced using iodine vapor or UV-light $(254 \mathrm{~nm})$. Melting points of the synthesized molecules were calculated using an electrical melting point apparatus (open capillary method) and are uncorrected. The infrared spectra were noted in the region from the 4000 to $400 \mathrm{~cm}^{-1}$ range on the Shimadzu FT-IR spectrometer, while ${ }^{1} \mathrm{H}$ and ${ }^{13} \mathrm{C}-\mathrm{NMR}$ spectra were recorded on the Bruker Advance-500 MHz and $125 \mathrm{MHz}$ spectrometer using DMSO$d_{6}$ or $\mathrm{CDCl}_{3}$ as an NMR solvent. Synapt-mass spectrometric detection was performed on UPLC-MS (Q-TOF-ESI; Waters Corp., Milford, MA, USA) using the ESI technique. Elemental analysis was executed on the CHNOS-Elemental analyzer (Vario EL III) and found to be $\pm 0.4 \%$, i.e., within the theoretical values.

3.1.1. Synthesis of Substituted (E)-1-(1-(4-(Benzyloxy)phenyl)ethylidene)-2-phenylhydrazine (3)

A solution of 1 (10 $\mathrm{mmol})$ and $2(15 \mathrm{mmol})$ in absolute ethanol $(30 \mathrm{~mL})$ was refluxed for $6-8 \mathrm{~h}$ in the presence of glacial acetic acid $(0.3 \mathrm{~mL})$. The reaction advancement was determined by the TLC method using a mixture of ethyl acetate: hexane (8:2). The product obtained was then washed, dried in shade, and recrystallized from ethanol [44]; white solid, yield: $78 \%$; m.p.: $123-125{ }^{\circ} \mathrm{C}$. 
3.1.2. Synthesis of Substituted

(E)-3-(4-(Benzyloxy)phenyl)-1-phenyl-1H-pyrazole-4-carbaldehyde (4)

Compound 3 in dry dimethylformamide at a temperature of $0-5{ }^{\circ} \mathrm{C}$ in a $100 \mathrm{~mL} \mathrm{RBF}$ was reacted with $\mathrm{POCl}_{3}$ (drop-wise addition) for a time interval of 15-20 min and then heated in a steam bath for a period of $2 \mathrm{~h}$; allowed to cool down to room temperature; poured in crushed ice; and then basified with a saturated solution of $\mathrm{NaHCO}_{3}$. The product obtained was then filtered, washed 2-3 times with water, dried, and recrystallized from ethanol to get yellow crystals (needle-like) [45].

White solid, yield: $72 \%$; m.p.: $127-129{ }^{\circ} \mathrm{C}, \mathrm{IR}\left(\mathrm{KBr}, \mathrm{cm}^{-1}\right): 3093$ (CH aromatic), $1710(\mathrm{C}=\mathrm{O}), 1633(\mathrm{C}=\mathrm{N})$, and $1626(\mathrm{C}=\mathrm{C}), 1255(\mathrm{C}-\mathrm{O}) .{ }^{1} \mathrm{H} \mathrm{NMR}\left(\mathrm{CDCl}_{3}, 500 \mathrm{MHz}\right) \delta(\mathrm{ppm})$ : $5.13\left(\mathrm{~s}, 2 \mathrm{H},-\mathrm{CH}_{2}\right.$-benzyloxy), $6.57(\mathrm{~d}, 2 \mathrm{H}, \mathrm{Ar}-\mathrm{H}, \mathrm{J}=8.0 \mathrm{~Hz}), 7.05(\mathrm{~d}, 2 \mathrm{H}, \mathrm{Ar}-\mathrm{H}, J=8.4 \mathrm{~Hz}), 7.21$ (d, 1H, Ar-H, J = 8.2 Hz), 7.30-7.59 (m, 4H, Ar-H), 7.67 (d, 2H, Ar-H, J = 8.8 Hz), 7.75-7.99 (m, 3H, Ar-H), 8.45 (s, 1H, pyrazole-CH), and 9.82 (s, 1H, CHO). Analysis calculated for $\mathrm{C}_{23} \mathrm{H}_{18} \mathrm{~N}_{2} \mathrm{O}_{2}$ : C, 77.93; H, 5.11; and N, 7.90. Found: C, 77.81; H, 5.16; and N, 7.81.

3.1.3. Synthesis of

(E)-3-(3-(4-(Benzyloxy)phenyl)-1-phenyl-1H-pyrazol-4-yl)-1-phenylprop-2-en-1-one derivatives $(5 \mathbf{a}-\mathbf{r})$

A mixture of 3-(4-(benzyloxy)phenyl)-1-phenyl-1H-pyrazole-4-carbaldehyde (4; $10 \mathrm{mmol})$ and different substituted acetophenones $(10 \mathrm{mmol})$ were dissolved in $20 \mathrm{~mL}$ ethanol. To this mixture, sodium hydroxide $(40 \%, 2 \mathrm{~mL})$ was added at $0-5{ }^{\circ} \mathrm{C}$ and then stirred at room temperature for $24 \mathrm{~h}$. Then, this reaction mixture was poured over crushed ice and acidified with dilute $\mathrm{HCl}(10 \%)$ until $\mathrm{pH}=5$. The light-yellow solid thus obtained was filtered, washed with water, dried, and recrystallized from ethanol to obtain the final product, i.e., (E)-3-(3-(4(benzyloxy)phenyl)-1-phenyl-1H-pyrazol-4-yl)-1-phenylprop-2-en-1-one (5a-r) [46].

(E)-3-(3-(4-(benzyloxy)phenyl)-1-phenyl-1H-pyrazol-4-yl)-1-phenylprop-2-en-1-one (5a):

White solid, yield: 74\%; m.p.: $190-194{ }^{\circ} \mathrm{C}$; IR (KBr, cm $\left.{ }^{-1}\right): 3045$ (CH aromatic), 2930 (CH aliphatic), $1710(\mathrm{C}=\mathrm{O}), 1643(\mathrm{C}=\mathrm{C}), 1627(\mathrm{C}=\mathrm{N})$, and $1245(\mathrm{C}-\mathrm{O}) ;{ }^{1} \mathrm{H}$ NMR $\left(\mathrm{CDCl}_{3}\right.$, $500 \mathrm{MHz}) ; \delta(\mathrm{ppm}): 5.15$ (s, 2H, $\mathrm{CH}_{2}$-benzyloxy), $7.12(\mathrm{~d}, 2 \mathrm{H}, \mathrm{Ar}-\mathrm{H}, \mathrm{J}=8.4 \mathrm{~Hz}), 7.05(\mathrm{~d}, 2 \mathrm{H}$ Ar-H, J = 8.4 Hz), $7.36(\mathrm{t}, 1 \mathrm{H}, \mathrm{Ar}-\mathrm{H}, J=7.5 \mathrm{~Hz}), 7.54-7.62(\mathrm{~m}, 5 \mathrm{H}, \mathrm{Ar}-\mathrm{H}), 7.64(\mathrm{~d}, 2 \mathrm{H}, \mathrm{Ar}-\mathrm{H}$, $J=8.8 \mathrm{~Hz}), 7.67(\mathrm{~d}, 2 \mathrm{H}, \mathrm{Ar}-\mathrm{H}, J=8.8 \mathrm{~Hz}), 7.74-7.85(\mathrm{~m}, 3 \mathrm{H}, \mathrm{Ar}-\mathrm{H}), 7.89(\mathrm{~d}, 2 \mathrm{H}, J=7.7 \mathrm{~Hz})$, $7.95(\mathrm{~d}, 1 \mathrm{H}$, chalcone $\mathrm{H}-7, J=15.6 \mathrm{~Hz}), 8.01(\mathrm{~d}, 1 \mathrm{H}$, chalcone-H-6, $J=15.7 \mathrm{~Hz})$, and 8.42 (s, $1 \mathrm{H}$, pyrazole-H); ${ }^{13} \mathrm{C} \mathrm{NMR}\left(\mathrm{CDCl}_{3}, 125 \mathrm{MHz}\right): \delta$ (ppm) 71.1 (benzyloxy $\left.\mathrm{CH}_{2}\right), 113.1$, 114.8, 119.4, 125.2, 126.7, 127.1, 127.7 (chalcone-C-7), 127.8, 128.4, 128.6, 129.1, 129.8, 130.2 (pyrazole-C-5), 134.5, 136.8, 137.9, 139.6 (pyrazole phenyl-C-1), 145.1 (chalcone-C-6), 150.7 (pyrazole-C-3), 159.1, and $189.8(\mathrm{C}=\mathrm{O})$; ESI-MS $(\mathrm{m} / \mathrm{z})$ : $456.18\left(\mathrm{M}^{+}\right)$. Analysis calculated for $\mathrm{C}_{31} \mathrm{H}_{24} \mathrm{~N}_{2} \mathrm{O}_{2}$ : C, 81.54; H, 5.29; N, 6.13; and O, 7.01. Found: C, 81.61; H, 5.22; and N, 6.17.

(E)-3-(3-(4-(benzyloxy)phenyl)-1-phenyl-1H-pyrazol-4-yl)-1-(2-chlorophenyl)prop-2-en1-one $(5 b)$ :

Off white solid, yield: $70 \%$; m.p.: $182-184{ }^{\circ} \mathrm{C}$; IR $\left(\mathrm{KBr}, \mathrm{cm}^{-1}\right): 3050$ (CH aromatic), 2935 (CH aliphatic), $1715(\mathrm{C}=\mathrm{O}), 1640(\mathrm{C}=\mathrm{N}), 1597(\mathrm{C}=\mathrm{C})$, and $1255(\mathrm{C}-\mathrm{O}), 745(\mathrm{C}-\mathrm{Cl}) ;{ }^{1} \mathrm{H}$ $\mathrm{NMR}\left(\mathrm{CDCl}_{3}, 500 \mathrm{MHz}\right) ; \delta(\mathrm{ppm}): 5.19\left(\mathrm{~s}, 2 \mathrm{H}, \mathrm{CH}_{2}\right.$-benzyloxy), $6.97(\mathrm{t}, 2 \mathrm{H}, \mathrm{Ar}-\mathrm{H}, J=8.7$ $\mathrm{Hz}), 7.08$ (d, 2H, Ar-H, J = 8.2 Hz), $7.31(\mathrm{~d}, 2 \mathrm{H}, \mathrm{Ar}-\mathrm{H}, J=9.6 \mathrm{~Hz}), 7.35(\mathrm{t}, 1 \mathrm{H}, \mathrm{Ar}-\mathrm{H}, J=8.2$ $\mathrm{Hz}), 7.57$ (d, 2H, Ar-H, J = 8.3 Hz), 7.50-7.68 (m, 3H, Ar-H), 7.74 (d, 2H, Ar-H, J = 8.4 Hz), $7.96(\mathrm{~d}, 2 \mathrm{H}, \mathrm{Ar}-\mathrm{H}, J=7.6 \mathrm{~Hz}), 7.98(\mathrm{~d}, 2 \mathrm{H}, \mathrm{Ar}-\mathrm{H}, J=8.7 \mathrm{~Hz}), 7.93(\mathrm{~d}, 1 \mathrm{H}$, chalcone-H-7, $J=$ $15.6 \mathrm{~Hz}), 8.06(\mathrm{~d}, 1 \mathrm{H}$, chalcone-H-6, $\mathrm{J}=15.7 \mathrm{~Hz})$, and $8.52\left(\mathrm{~s}, 1 \mathrm{H}\right.$, pyrazole-H); and ${ }^{13} \mathrm{C}$ NMR $\left(\mathrm{CDCl}_{3}, 125 \mathrm{MHz}\right): \delta$ (ppm): 71.4 (benzyloxy- $\left.\mathrm{CH}_{2}\right), 113.8,114.7,119.5,125.6,126.4,127.2$, 127.8 (chalcone-C-7), 127.9, 128.4, 128.8, 129.5, 130.4 (pyrazole-C-5), 130.6, 131.8 (C-Cl), 136.2, 137.9, 139.4 (pyrazole-phenyl-C-1), 144.7 (Chalcone-C-6), 150.5 (pyrazole-C-3), 159.4, and $189.4(\mathrm{C}=\mathrm{O})$. ESI-MS $(\mathrm{m} / z): 491.88\left(\mathrm{M}^{+}+1\right)$ and $492.75\left(\mathrm{M}^{+}+2\right)$. Analysis calculated for $\mathrm{C}_{31} \mathrm{H}_{23} \mathrm{ClN}_{2} \mathrm{O}_{2}$ : C, 75.82; $\mathrm{H}, 4.71$; and N, 5.70. Found: C, 75.91; H, 4.62; and N, 5.75.

(E)-3-(3-(4-(benzyloxy)phenyl)-1-phenyl-1H-pyrazol-4-yl)-1-(3-nitrophenyl)prop-2-en1-one $(5 c)$ :

Orange red solid, yield: $78 \%$; m.p.: $203-205^{\circ} \mathrm{C}$; IR $\left(\mathrm{KBr}, \mathrm{cm}^{-1}\right): 3046(\mathrm{CH}$ aromatic), 2940 ( $\mathrm{CH}$ aliphatic), $1690(\mathrm{C}=\mathrm{O}), 1625(\mathrm{C}=\mathrm{N}), 1612(\mathrm{C}=\mathrm{C}), 1510$ and $1350\left(\mathrm{NO}_{2}\right)$, and 1245 
(C-O); ${ }^{1} \mathrm{H}$ NMR ( $\left.\mathrm{CDCl}_{3}, 500 \mathrm{MHz}\right) ; \delta$ (ppm): 5.11 (s, 2H, $\mathrm{CH}_{2}$-benzyloxy), 7.35 (d, 2H, Ar-H, $J=7.8 \mathrm{~Hz}), 7.44(\mathrm{~d}, 2 \mathrm{H}, \mathrm{Ar}-\mathrm{H}, J=7.8 \mathrm{~Hz}), 7.58(\mathrm{t}, 1 \mathrm{H}, \mathrm{Ar}-\mathrm{H}, J=8.0 \mathrm{~Hz}), 7.63(\mathrm{~d}, 2 \mathrm{H}, \mathrm{Ar}-\mathrm{H}$, $J=8.8 \mathrm{~Hz}), 7.66-7.78(\mathrm{~m}, 5 \mathrm{H}, \mathrm{Ar}-\mathrm{H}), 7.80(\mathrm{~d}, 1 \mathrm{H}$, chalcone-H-7, $J=15.5 \mathrm{~Hz}), 7.88(\mathrm{~d}, 2 \mathrm{H}$, Ar-H, $J=7.6 \mathrm{~Hz}), 8.00(\mathrm{~d}, 1 \mathrm{H}$, chalcone-H-6, $J=15.7 \mathrm{~Hz}), 8.02(\mathrm{t}, 1 \mathrm{H}, \mathrm{Ar}-\mathrm{H}, J=8.8 \mathrm{~Hz}), 8.42$ $(\mathrm{s}, 1 \mathrm{H}, \mathrm{Ar}-\mathrm{H}), 8.56(\mathrm{~d}, 2 \mathrm{H}, \mathrm{Ar}-\mathrm{H}, J=9.4 \mathrm{~Hz})$, and $8.48\left(\mathrm{~s}, 1 \mathrm{H}\right.$, pyrazole-H); ${ }^{13} \mathrm{C} \mathrm{NMR}\left(\mathrm{CDCl}_{3}\right.$, $125 \mathrm{MHz}$ ): $\delta$ (ppm) 71.2 (benzyloxy- $\mathrm{CH}_{2}$ ), 113.3, 114.5, 119.2, 123.7, 125.6, 126.6, 127.1, 127.6 (chalcone-C-7), 128.3, 128.8, 129.2, 129.4, 130.2 (pyrazole-C-5), 130.6, 134.9, 136.8, 138.5, 139.6 (pyrazole-phenyl-C-1), 143.3 (chalcone-C-6), $148.6\left(\right.$ Ar-C- $\left.\mathrm{NO}_{2}\right), 150.6$ (pyrazole-C-3), 159.1, and $189.9(\mathrm{C}=\mathrm{O})$; ESI-MS $(\mathrm{m} / \mathrm{z}): 501.17\left(\mathrm{M}^{+}\right)$. Analysis calculated for $\mathrm{C}_{31} \mathrm{H}_{23} \mathrm{~N}_{3} \mathrm{O}_{4}$ : C, 74.21; $\mathrm{H}, 4.61$; and N, 8.31. Found: $\mathrm{C}, 74.26 ; \mathrm{H}, 4.55$; and N, 8.42.

(E)-3-(3-(4-(benzyloxy)phenyl)-1-phenyl-1H-pyrazol-4-yl)-1-(3-hydroxyphenyl)prop-2en-1-one (5d):

White buff solid, yield: $64 \%$; m.p.: $184-186^{\circ} \mathrm{C}$; IR $\left(\mathrm{KBr}, \mathrm{cm}^{-1}\right)$ : $3445(\mathrm{OH}), 3055(\mathrm{CH}$ aromatic), 2958 ( $\mathrm{CH}$ aliphatic), $1705(\mathrm{C}=\mathrm{O}), 1620(\mathrm{C}=\mathrm{N}), 1597(\mathrm{C}=\mathrm{C})$, and $1245(\mathrm{C}-\mathrm{O}) ;{ }^{1} \mathrm{H}$ NMR $\left(\mathrm{CDCl}_{3}, 500 \mathrm{MHz}\right) ; \delta(\mathrm{ppm}): 5.22\left(\mathrm{~s}, 2 \mathrm{H}, \mathrm{CH}_{2}\right.$-benzyloxy), $5.42(\mathrm{~s}, 1 \mathrm{H}, \mathrm{OH}), 6.72(\mathrm{~d}$, $2 \mathrm{H}, \mathrm{Ar}-\mathrm{H}, J=7.6 \mathrm{~Hz}), 6.94(\mathrm{~d}, 2 \mathrm{H}, \mathrm{Ar}-\mathrm{H}, J=7.8 \mathrm{~Hz}), 7.14(\mathrm{~s}, 1 \mathrm{H}, \mathrm{Ar}-\mathrm{H}), 7.24(\mathrm{t}, 2 \mathrm{H}, \mathrm{Ar}-\mathrm{H}$, $J=6.8 \mathrm{~Hz}), 7.31(\mathrm{~d}, 2 \mathrm{H}, \mathrm{Ar}-\mathrm{H}, J=6.4 \mathrm{~Hz}), 7.42-7.53(\mathrm{~m}, 3 \mathrm{H}, \mathrm{Ar}-\mathrm{H}), 7.74(\mathrm{~d}, 1 \mathrm{H}$, chalcone$\mathrm{H}-7, J=15.8 \mathrm{~Hz}), 7.58-7.76(\mathrm{~m}, 4 \mathrm{H}$, Ar-pyrazole), $7.94(\mathrm{~d}, 1 \mathrm{H}$, chalcone-H-6, $J=16.0 \mathrm{~Hz})$, $7.98(\mathrm{~d}, 2 \mathrm{H}, \mathrm{Ar}-\mathrm{H}, J=7.8 \mathrm{~Hz})$, and $8.03\left(\mathrm{~s}, 1 \mathrm{H}\right.$. pyrazole-H); ${ }^{13} \mathrm{C} \mathrm{NMR}\left(\mathrm{CDCl}_{3}, 125 \mathrm{MHz}\right)$ : $\delta$ (ppm) 70.8 (benzyloxy- $\mathrm{CH}_{2}$ ), 113.6, 114.7, 117.3, 119.4, 121.6, 123.2, 125.3, 126.3, 127.1, 127.4 (chalcone-C-7), 127.9, 128.3, 129.4, 130.5 (pyrazole-C-5), 131.4, 136.9, 137.3, 139.3 (pyrazole-phenyl-C-1), 146.4 (chalcone-C-6), 150.2 (pyrazole-C-3), 159.1, 164.8 (C-OH), and $196.1(\mathrm{C}=\mathrm{O})$; ESI-MS $(\mathrm{m} / \mathrm{z})$ : $472.18\left(\mathrm{M}^{+}\right)$. Analysis calculated for $\mathrm{C}_{31} \mathrm{H}_{24} \mathrm{~N}_{2} \mathrm{O}_{3}: \mathrm{C}, 78.80 ; \mathrm{H}$, 5.13; and N, 5.94. Found: C, 78.85; H, 5.17; and N, 5.89

(E)-3-(3-(4-(benzyloxy)phenyl)-1-phenyl-1H-pyrazol-4-yl)-1-(4-chlorophenyl)prop-2-en1-one (5e):

White buff solid, yield: $76 \%$; m.p.: $212-214{ }^{\circ} \mathrm{C}$; IR $\left(\mathrm{KBr}, \mathrm{cm}^{-1}\right)$ : 3080 ( $\mathrm{CH}$ aromatic), $2960(\mathrm{CH}$ aliphatic), $1720(\mathrm{C}=\mathrm{O}), 1657(\mathrm{C}=\mathrm{C}), 1610(\mathrm{C}=\mathrm{N}), 1235(\mathrm{C}-\mathrm{O})$, and $790(\mathrm{C}-\mathrm{Cl})$; ${ }^{1} \mathrm{H}$ NMR $\left(\mathrm{CDCl}_{3}, 500 \mathrm{MHz}\right) ; \delta(\mathrm{ppm}): 5.17$ (s, 2H, $\mathrm{CH}_{2}$-benzyloxy), 7.15 (d, 2H, Ar-H, $J=8.7 \mathrm{~Hz}), 7.28(\mathrm{~d}, 2 \mathrm{H}, \mathrm{Ar}-\mathrm{H}, J=7.8 \mathrm{~Hz}), 7.31-7.43(\mathrm{~m}, 3 \mathrm{H}, \mathrm{Ar}-\mathrm{H}), 7.46-7.55(\mathrm{~m}, 4 \mathrm{H}, \mathrm{Ar}-\mathrm{H})$, $7.59(\mathrm{~d}, 2 \mathrm{H}, \mathrm{Ar}-\mathrm{H}, J=8.4 \mathrm{~Hz}), 7.64(\mathrm{~d}, 2 \mathrm{H}, \mathrm{Ar}-\mathrm{H}, J=8.4 \mathrm{~Hz}), 7.83(\mathrm{t}, 3 \mathrm{H}, \mathrm{Ar}-\mathrm{H}, J=7.8 \mathrm{~Hz}), 7.95$ $(\mathrm{d}, 1 \mathrm{H}$, chalcone- $\mathrm{H}-7, \mathrm{~J}=15.6 \mathrm{~Hz}), 8.05(\mathrm{~d}, 1 \mathrm{H}$, chalcone-H-6), and $8.38(\mathrm{~s}, 1 \mathrm{H}$, pyrazole-H); ${ }^{13} \mathrm{C} \mathrm{NMR}\left(\mathrm{CDCl}_{3}, 125 \mathrm{MHz}\right): \delta$ (ppm) 69.7 (benzyloxy- $\left.\mathrm{CH}_{2}\right), 112.8,115.9,118.9,119.2,124.7$, 126.1, 126.5, 128.5, 128.8 (chalcone-C-7), 128.9, 129.2, 129.9, 130.3 (pyrazole-C-5), 137.4, 139.9 (pyrazole-phenyl-C-1), 146.8 (chalcone-C-6), 150.7 (pyrazole-C-3), 158.6, and $189.7(\mathrm{C}=\mathrm{O}$ ); ESI-MS $(m / z): 491.88\left(\mathrm{M}^{+}+1\right)$ and $492.75\left(\mathrm{M}^{+}+2\right)$. Analysis calculated for $\mathrm{C}_{31} \mathrm{H}_{23} \mathrm{ClN}_{2} \mathrm{O}_{2}$ : C, 75.82; H, 4.73, and N, 5.70. Found: C, 75.88; H, 4.69; and N, 5.75.

(E)-3-(3-(4-(benzyloxy)phenyl)-1-phenyl-1H-pyrazol-4-yl)-1-(4-fluorophenyl)prop-2-en1-one (5f):

Off white solid, yield: $66 \%$; m.p.: $168-170{ }^{\circ} \mathrm{C}$; $\mathrm{IR}\left(\mathrm{KBr}, \mathrm{cm}^{-1}\right)$ : 3105 (CH aromatic), 2950 (CH aliphatic), $1708(\mathrm{C}=\mathrm{O}), 1605(\mathrm{C}=\mathrm{N}), 1593(\mathrm{C}=\mathrm{C}), 1210(\mathrm{C}-\mathrm{O})$, and $755(\mathrm{C}-\mathrm{F}) ;{ }^{1} \mathrm{H}$ NMR $\left(\mathrm{CDCl}_{3}, 500 \mathrm{MHz}\right) ; \delta(\mathrm{ppm}): 5.18\left(\mathrm{~s}, 2 \mathrm{H}, \mathrm{CH}_{2}\right.$-benzyloxy), $7.16(\mathrm{~d}, 2 \mathrm{H}, \mathrm{Ar}-\mathrm{H}, J=8.7 \mathrm{~Hz}), 7.33$ $(\mathrm{t}, 1 \mathrm{H}, \mathrm{Ar}-\mathrm{H}, J=8.2 \mathrm{~Hz}), 7.43(\mathrm{~d}, 2 \mathrm{H} \mathrm{Ar}-\mathrm{H}, J=8.8 \mathrm{~Hz}), 7.54(\mathrm{~d}, 2 \mathrm{H}, \mathrm{Ar}-\mathrm{H}, J=8.2 \mathrm{~Hz}), 7.52-7.72$ $(\mathrm{m}, 5 \mathrm{H}, \mathrm{Ar}-\mathrm{H}), 7.74(\mathrm{~d}, 2 \mathrm{H}, \mathrm{Ar}-\mathrm{H}, J=8.4 \mathrm{~Hz}), 7.76(\mathrm{~d}, 1 \mathrm{H}$, chalcone-H-7, J = $15.3 \mathrm{~Hz}), 7.96(\mathrm{~d}$, $2 \mathrm{H}, \mathrm{Ar}-\mathrm{H}, J=7.6 \mathrm{~Hz}), 7.98(\mathrm{~d}, 2 \mathrm{H}, \mathrm{Ar}-\mathrm{H}, J=8.7 \mathrm{~Hz}), 8.06(\mathrm{~d}, 1 \mathrm{H}$, chalcone-H-6, $J=15.7 \mathrm{~Hz})$, and $8.54\left(\mathrm{~s}, 1 \mathrm{H}\right.$, pyrazole-H); ${ }^{13} \mathrm{C}$ NMR $\left(\mathrm{CDCl}_{3}, 125 \mathrm{MHz}\right): \delta$ (ppm) 70.7 (benzyloxy- $\left.\mathrm{CH}_{2}\right)$, 113.2, 114.5, 116.0, 119.6, 125.3, 126.4, 127.2, 127.4 (chalcone-C-7), 127.8, 128.6, 129.4, 130.4 (pyrazole-C-5), 131.8, 133.6, 136.1, 136.6, 139.7 (pyrazole-phenyl-C-1), 145.3 (chalcone-C-6), 150.8 (C-3-pyrazole), 159.6, $164.8(\mathrm{C}-\mathrm{F})$, and $189.5(\mathrm{C}=\mathrm{O})$; ESI-MS $(\mathrm{m} / \mathrm{z}): 477.70\left(\mathrm{M}^{+}+1\right)$. Analysis calculated for $\mathrm{C}_{31} \mathrm{H}_{23} \mathrm{FN}_{2} \mathrm{O}_{2}: \mathrm{C}, 78.48 ; \mathrm{H}, 4.90$; and N, 5.92. Found: $\mathrm{C}, 78.55 ; \mathrm{H}$, 4.95; and N, 5.86 .

(E)-3-(3-(4-(benzyloxy)phenyl)-1-phenyl-1H-pyrazol-4-yl)-1-(4-bromophenyl)prop-2-en1-one $(5 \mathrm{~g})$ 
Off white solid, yield: $62 \%$; m.p.: $178-180^{\circ} \mathrm{C}$; IR $\left(\mathrm{KBr}, \mathrm{cm}^{-1}\right)$ : $3095(\mathrm{CH}$ aromatic), 2965 (CH aliphatic), $1708(\mathrm{C}=\mathrm{O}), 1610(\mathrm{C}=\mathrm{N}), 1585(\mathrm{C}=\mathrm{C}), 1210(\mathrm{C}-\mathrm{O})$, and $665(\mathrm{C}-\mathrm{Br}) ;{ }^{1} \mathrm{H}$ NMR ( $\left.\mathrm{CDCl}_{3}, 500 \mathrm{MHz}\right) ; \delta(\mathrm{ppm}): 5.14\left(\mathrm{~s}, 2 \mathrm{H}, \mathrm{CH}_{2}\right.$-benzyloxy), 7.10-7.97 (m, 20H, aromatic $\mathrm{H}), 7.90(\mathrm{~d}, 1 \mathrm{H}, \mathrm{CH}=\mathrm{CH}, \mathrm{Cis}, J=15.5 \mathrm{~Hz}), 7.83(\mathrm{~d}, 1 \mathrm{H}, \mathrm{CH}=\mathrm{CH}, J=9 \mathrm{~Hz})$, and $8.33(\mathrm{~s}$, $1 \mathrm{H}, \mathrm{CH}$ of pyrazole); ${ }^{13} \mathrm{C}$ NMR $\left(\mathrm{CDCl}_{3}, 125 \mathrm{MHz}\right): \delta$ (ppm) 70.1 (benzyloxy- $\left.\mathrm{CH}_{2}\right), 115.24$, $118.01,119.36,120.56,124.96,125.86,127.28,127.52,127.76,128.10,128.68$ (chalcone-C-7), 129.61 (pyrazole-C-5), 129.92, 130.10 (pyrazole-phenyl-C-1), 131.90, 136.19 (chalcone-C-6), 136.79 (pyrazole-C-3), 139.40, 153.78 (C-Br), 159.36, and 188.92 (C=O); ESI-MS ( $m / z)$ : 537.09 $\left(\mathrm{M}^{+}+1\right)$. Analysis calculated for $\mathrm{C}_{31} \mathrm{H}_{23} \mathrm{BrN}_{2} \mathrm{O}_{2}: \mathrm{C}, 69.55 ; \mathrm{H}, 4.31$; and N, 5.24. Found: $\mathrm{C}$, 69.62; $\mathrm{H}, 4.36$; and $\mathrm{N}, 5.20$.

(E)-3-(3-(4-(benzyloxy)phenyl)-1-phenyl-1H-pyrazol-4-yl)-1-(4-hydroxyphenyl)prop-2en-1-one (5h):

White buff solid, yield: $65 \%$; m.p.: $167-169^{\circ} \mathrm{C}$; IR $\left(\mathrm{KBr}, \mathrm{cm}^{-1}\right)$ : $3415(\mathrm{OH}), 3065(\mathrm{CH}$ aromatic), 2934 ( $\mathrm{CH}$ aliphatic), $1695(\mathrm{C}=\mathrm{O}), 1618(\mathrm{C}=\mathrm{N}), 1605(\mathrm{C}=\mathrm{C})$, and $1248(\mathrm{C}-\mathrm{O}) ;{ }^{1} \mathrm{H}$ NMR $\left(\mathrm{CDCl}_{3}, 500 \mathrm{MHz}\right) ; \delta(\mathrm{ppm}): 5.20\left(\mathrm{~s}, 2 \mathrm{H}, \mathrm{CH}_{2}\right.$-benzyloxy), $5.68(\mathrm{~s}, 1 \mathrm{H}, \mathrm{OH}), 6.56(\mathrm{~d}$, $2 \mathrm{H}, \mathrm{Ar}-\mathrm{H}, J=7.2 \mathrm{~Hz}), 6.80(\mathrm{~d}, 2 \mathrm{H}, \mathrm{Ar}-\mathrm{H}, J=7.6 \mathrm{~Hz}), 7.27(\mathrm{t}, 2 \mathrm{H}, \mathrm{Ar}-\mathrm{H}, J=7.3 \mathrm{~Hz}), 7.31(\mathrm{~d}, 2 \mathrm{H}$, Ar-H, J = 6.4 Hz), 7.38-7.48 (m, 3H, Ar-H), $7.66(\mathrm{~d}, 1 \mathrm{H}$, chalcone- $\mathrm{H}-7, \mathrm{~J}=15.5 \mathrm{~Hz}), 7.69-780$ (m, 4H, Ar-pyrazole), $7.82(\mathrm{~d}, 1 \mathrm{H}$, chalcone- $\mathrm{H}-6, J=15.5 \mathrm{~Hz}), 7.92(\mathrm{~d}, 2 \mathrm{H}, \mathrm{Ar}-\mathrm{H}, J=7.4 \mathrm{~Hz})$, and 8.01 (s, $1 \mathrm{H}$. pyrzole-H); ${ }^{13} \mathrm{C} \mathrm{NMR}\left(\mathrm{CDCl}_{3}, 125 \mathrm{MHz}\right): \delta(\mathrm{ppm}) 71.8$ (benzyloxy- $\left.\mathrm{CH}_{2}\right)$, 113.2, 114.5, 119.8, 125.8, 126.4, 127.2, 127.5 (chalcone-C-7), 127.9, 128.4, 128.8, 129.7, 130.5 (pyrazole-C-5), 130.8, 131.5, 136.8, 139.9 (pyrazole-phenyl-C-1), 146.4 (chalcone-C-6), 150.7 (pyrazole-C-3), 159.6, 164.5 (C-OH), and $189.8(\mathrm{C}=\mathrm{O})$; ESI-MS $(\mathrm{m} / \mathrm{z}): 472.18\left(\mathrm{M}^{+}\right)$. Analysis calculated for $\mathrm{C}_{31} \mathrm{H}_{24} \mathrm{~N}_{2} \mathrm{O}_{3}$ : C, 78.79; $\mathrm{H}, 5.12$; and $\mathrm{N}$, 5.93. Found: $\mathrm{C}, 78.84 ; \mathrm{H}, 5.16$; and $\mathrm{N}, 5.88$

(E)-3-(3-(4-(benzyloxy)phenyl)-1-phenyl-1H-pyrazol-4-yl)-1-(4-nitrophenyl)prop-2-en1-one (5i):

Orange red solid, yield: $82 \%$; m.p.: $223-225^{\circ} \mathrm{C} \mathrm{IR}\left(\mathrm{KBr}, \mathrm{cm}^{-1}\right)$ : 3035 (CH aromatic), 2956 ( $\mathrm{CH}$ aliphatic), $1675(\mathrm{C}=\mathrm{O}), 1630(\mathrm{C}=\mathrm{N}), 1576(\mathrm{C}=\mathrm{C}), 1505$ and $1363\left(\mathrm{NO}_{2}\right)$, and $1238(\mathrm{C}-$ $\mathrm{O}) ;{ }^{1} \mathrm{H}$ NMR $\left(\mathrm{CDCl}_{3}, 500 \mathrm{MHz}\right) ; \delta$ (ppm): 5.12 (s, 2H, $\mathrm{CH}_{2}$-benzyloxy), 7.13 (d, 2H, $\mathrm{Ar}-\mathrm{H}, J$ $=7.8 \mathrm{~Hz}), 7.42(\mathrm{~d}, 2 \mathrm{H}, \mathrm{Ar}-\mathrm{H}, J=8.6 \mathrm{~Hz}), 7.54(\mathrm{t}, 1 \mathrm{H}, \mathrm{Ar}-\mathrm{H}, J=7.4 \mathrm{~Hz}), 7.62(\mathrm{~d}, 2 \mathrm{H}, \mathrm{Ar}-\mathrm{H}$, $J=8.8 \mathrm{~Hz}), 7.66-7.76(\mathrm{~m}, 5 \mathrm{H}, \mathrm{Ar}-\mathrm{H}), 7.82(\mathrm{~d}, 1 \mathrm{H}$, chalcone-H-7, $J=15.6 \mathrm{~Hz}), 7.86(\mathrm{~d}, 2 \mathrm{H}$, Ar- $\mathrm{H}, J=7.6 \mathrm{~Hz}), 8.08(\mathrm{~d}, 1 \mathrm{H}$, chalcone- $\mathrm{H}-6, J=15.8 \mathrm{~Hz}), 8.16(\mathrm{~d}, 2 \mathrm{H}, \mathrm{Ar}-\mathrm{H}, J=8.6 \mathrm{~Hz})$, $8.30(\mathrm{~d}, 2 \mathrm{H}, \mathrm{Ar}-\mathrm{H}, J=8.8 \mathrm{~Hz})$, and $8.38(\mathrm{~s}, 1 \mathrm{H}$, pyrazole- $\mathrm{H}) ;{ }^{13} \mathrm{C} \mathrm{NMR}\left(\mathrm{CDCl}_{3}, 125 \mathrm{MHz}\right)$ : $\delta$ (ppm) 69.5 (benzyloxy- $\mathrm{CH}_{2}$ ), 113.3 (pyrazole-C-4), 115.2, 119.6, 122.4, 125.6, 126.6, 127.5, 127.4 (chalcone-C-7), 127.8, 128.1, 128.6, 129.2, 130.8 (pyrazole-C-5), 130.6, 136.5, 139.6 (pyrazole-phenyl-C-1), 142.5 (chalcone-C-6), 150.5 (pyrazole-C-3), $153.6\left(\mathrm{C}-\mathrm{NO}_{2}\right)$, and 159.2, $189.3(\mathrm{C}=\mathrm{O})$; ESI-MS $(\mathrm{m} / \mathrm{z})$ : $501.17\left(\mathrm{M}^{+}\right)$. Analysis calculated for $\mathrm{C}_{31} \mathrm{H}_{23} \mathrm{~N}_{3} \mathrm{O}_{4}: \mathrm{C}, 74.27 ; \mathrm{H}$, 4.64; and N, 8.41. Found: C, 74.32; H, 4.58; and N, 8.46.

(E)-3-(3-(4-(benzyloxy)phenyl)-1-phenyl-1H-pyrazol-4-yl)-1-(p-tolyl)prop-2-en-1-one (5j):

Off white solid, yield: $78 \%$; m.p.: $205-207^{\circ} \mathrm{C}$; IR $\left(\mathrm{KBr} \mathrm{cm}^{-1}\right)$ : $3028(\mathrm{CH}$ aromatic), $2960\left(\mathrm{C}-\mathrm{H}\right.$ str in $\left.\mathrm{CH}_{3}\right), 2968$ (CH aliphatic), $1724(\mathrm{C}=\mathrm{O}), 1645(\mathrm{C}=\mathrm{N}), 1618(\mathrm{C}=\mathrm{C})$, and 1205 (C-O); ${ }^{1} \mathrm{H} \mathrm{NMR}\left(\mathrm{CDCl}_{3}, 500 \mathrm{MHz}\right) ; \delta(\mathrm{ppm}): 3.75\left(\mathrm{~s}, 3 \mathrm{H}, \mathrm{CH}_{3}\right), 5.16$ (s, $2 \mathrm{H}, \mathrm{CH}_{2}$-benzyloxy), $7.14(\mathrm{~d}, 2 \mathrm{H}, \mathrm{Ar}-\mathrm{H}, J=7.1 \mathrm{~Hz}), 7.29(\mathrm{~d}, 2 \mathrm{H}, \mathrm{Ar}-\mathrm{H}, J=5.1 \mathrm{~Hz}), 7.54(\mathrm{t}, 3 \mathrm{H}, \mathrm{Ar}-\mathrm{H}, J=8.1$ $\mathrm{Hz}), 7.62(\mathrm{~d}, 2 \mathrm{H}, \mathrm{Ar}-\mathrm{H}, J=8.4 \mathrm{~Hz}), 7.64-7.72(\mathrm{~m}, 3 \mathrm{H}, \mathrm{Ar}-\mathrm{H}), 7.74(\mathrm{~d}, 1 \mathrm{H}$, chalcone-H-7, $J=15.4 \mathrm{~Hz}), 7.76-7.81(\mathrm{~m}, 4 \mathrm{H}, \mathrm{Ar}-\mathrm{H}), 7.86(\mathrm{~d}, 1 \mathrm{H}$, chalcone-H-6, J = $15.1 \mathrm{~Hz}), 7.95(\mathrm{~d}, 2 \mathrm{H}$, $\mathrm{Ar}-\mathrm{H}, J=7.5 \mathrm{~Hz})$, and $8.52\left(\mathrm{~s}, 1 \mathrm{H}\right.$. pyrazole-H); ${ }^{13} \mathrm{C} \mathrm{NMR}\left(\mathrm{CDCl}_{3}, 125 \mathrm{MHz}\right): \delta(\mathrm{ppm}) 20.5$ $\left(\mathrm{Ar}-\mathrm{CH}_{3}\right), 70.8$ (benzyloxy-CH $\left.\mathrm{C}_{2}\right), 11.9$ (pyrazole-C-4), 115.3, 118.3, 119.2, 124.9, 126.1, 126.4, 128.2 (chalcone-C-7), 128.3, 128.9, 129.1, 129.7, 130.0 (pyrazole-C-5), 139.4 (pyrazol-phenylC-1), 146.8 (chalcone-C-6), 150.7 (pyrazole-C-3), 158.6, and 189.7 (C=O); ESI-MS $(\mathrm{m} / \mathrm{z}$ ): $471.20\left(\mathrm{M}^{+}+1\right)$. Analysis calculated for $\mathrm{C}_{32} \mathrm{H}_{26} \mathrm{~N}_{2} \mathrm{O}_{2}$ : C, 81.67; $\mathrm{H}, 5.59$; and $\mathrm{N}, 5.96$. Found: C, 81.73; $\mathrm{H}, 5.53$; and N, 6.02 .

(E)-3-(3-(4-(benzyloxy)phenyl)-1-phenyl-1H-pyrazol-4-yl)-1-(4-methoxyphenyl)prop2-en-1-one (5k): 
Greenish solid, yield: $68 \%$; m.p.: $187-189^{\circ} \mathrm{C}$; IR (KBr, $\left.\mathrm{cm}^{-1}\right): 3090(\mathrm{CH}$ aromatic), 2970 (CH aliphatic), $1745(\mathrm{C}=\mathrm{O}), 1655(\mathrm{C}=\mathrm{N}), 1633(\mathrm{C}=\mathrm{C})$, and $1267\left(\mathrm{OCH}_{3}\right), 1220(\mathrm{C}-\mathrm{O}) ;{ }^{1} \mathrm{H}$ NMR $\left(\mathrm{CDCl}_{3}, 500 \mathrm{MHz}\right) ; \delta$ (ppm): $3.86\left(\mathrm{~s}, 3 \mathrm{H}, \mathrm{OCH}_{3}\right), 5.14\left(\mathrm{~s}, 2 \mathrm{H}, \mathrm{CH}_{2}\right.$-benzyloxy), 7.10-7.97 $(\mathrm{m}, 20 \mathrm{H}$, aromatic $\mathrm{H}), 7.90(\mathrm{~d}, 1 \mathrm{H}, \mathrm{CH}=\mathrm{CH}$ Cis, $J=8.5 \mathrm{~Hz}), 7.83(\mathrm{~d}, 1 \mathrm{H}, \mathrm{CH}=\mathrm{CH}, J=8 \mathrm{~Hz})$, and 8.53 (s, $1 \mathrm{H}, \mathrm{CH}$ of pyrazole); ${ }^{13} \mathrm{C} \mathrm{NMR}\left(\mathrm{CDCl}_{3}, 125 \mathrm{MHz}\right): \delta(\mathrm{ppm}) 70.1\left(\mathrm{Ar}-\mathrm{OCH}_{3}\right)$, 70.5 (benzyloxy-CH${ }_{2}$ ), 115.15 (pyrazole-C-4), 119.34, 119.74, 122.36 (chalcone-C-7), 124.10, 127.53, 127.93, 128.13, 128.68 (pyrazole-C-5), 129.70, 130.70, 131.20 (phenyl-pyrazole-C-1), 136.70 (chalcone-C-6), 139.06 (pyrazole-C-3), 154.51, 159.75, and 185.24 (C=O); ESI-MS $(m / z)$ : $487.22\left(\mathrm{M}^{+}+1\right)$. Analysis calculated for $\mathrm{C}_{32} \mathrm{H}_{26} \mathrm{~N}_{2} \mathrm{O}_{3}: \mathrm{C}, 78.97 ; \mathrm{H}, 5.40$; and N, 5.78 . Found: C, 78.94; H, 5.34; and N, 5.84.

(E)-3-(3-(4-(benzyloxy)phenyl)-1-phenyl-1H-pyrazol-4-yl)-1-(3,4-dichlorophenyl)prop2-en-1-one (51):

Off white solid, yield: $76 \%$; m.p.: $243-245^{\circ} \mathrm{C}$; IR $\left(\mathrm{KBr}, \mathrm{cm}^{-1}\right): 3030(\mathrm{CH}$ aromatic), 2980 (CH aliphatic), $1745(\mathrm{C}=\mathrm{O}), 1653(\mathrm{C}=\mathrm{N}), 1637(\mathrm{C}=\mathrm{C}), 1225(\mathrm{C}-\mathrm{O})$, and $785(\mathrm{C}-\mathrm{Cl}){ }^{1} \mathrm{H}$ NMR $\left(\mathrm{CDCl}_{3}, 500 \mathrm{MHz}\right) ; \delta$ (ppm): 5.17 (s, 2H, $\mathrm{CH}_{2}$-benzyloxy), 7.16 (d, 2H, Ar-H, J = 8.4 Hz), 7.25 (s, 1H Ar-H), 7.36 (d, 2H, Ar-H, J = 7.6 Hz), 7.48-7.51 (d, 2x 2H, Ar-H, J = 8.4 Hz), 7.55 (s, 1H, Ar-H), 7.56 (s, 1H, Ar-H), 7.58 (s, 1H, Ar-H), 7.67 (d, 2H, Ar-H, J = 8.4 Hz), 7.79-7.83 $(\mathrm{m}, 3 \mathrm{H}, \mathrm{Ar}-\mathrm{H}), 7.95$ (d, 1H, chalcone-H, $J=15.6 \mathrm{~Hz}), 8.05(\mathrm{~d}, 1 \mathrm{H}$, chalcone-H, $J=16.2 \mathrm{~Hz})$, and 8.37 (s, $1 \mathrm{H}$, pyrazole-H); ${ }^{13} \mathrm{C} \mathrm{NMR}\left(\mathrm{CDCl}_{3}, 125 \mathrm{MHz}\right): \delta(\mathrm{ppm}) 70.2$ (benzyloxy- $\left.\mathrm{CH}_{2}\right)$, 113.4, 114.4, 119.6, 125.5, 126.2, 127.2, 127.4 (chalcone-C-7), 127.7, 128.3, 128.6, 128.8, 129.5, 130.2 (pyrazole-C-5), 130.6, 131.4, 133.6, 136.6, 137.3, 139.3 (C-Cl), 139.8 (phenyl-C-1), 145.2 (chalcone-C-6), 150.3 (pyrazole-C-3), 159.1, and $189.5(\mathrm{C}=\mathrm{O})$; ESI-MS (m/z): $524.11\left(\mathrm{M}^{+}+1\right)$, $525.08\left(\mathrm{M}^{+}+2\right)$, and $526.06\left(\mathrm{M}^{+}+4\right)$. Analysis calculated for $\mathrm{C}_{31} \mathrm{H}_{22} \mathrm{Cl}_{2} \mathrm{~N}_{2} \mathrm{O}_{2}: \mathrm{C}, 70.85 ; \mathrm{H}$, 4.23; and N, 5.31. Found: C, 70.92; H, 4.18; and N, 5.41 .

(E)-3-(3-(4-(benzyloxy)phenyl)-1-phenyl-1H-pyrazol-4-yl)-1-(2,4dichlorophenyl)prop2-en-1-one $(5 \mathrm{~m})$ :

Off white solid, yield: $67 \%$; m.p.: $192-194^{\circ} \mathrm{C}$; IR (KBr, $\left.\mathrm{cm}^{-1}\right): 3065$ (CH aromatic), 2985 (CH aliphatic), $1753(\mathrm{C}=\mathrm{O}), 1620(\mathrm{C}=\mathrm{N}), 1598(\mathrm{C}=\mathrm{C}), 1275(\mathrm{C}-\mathrm{O})$, and $785(\mathrm{C}-\mathrm{Cl}) ;{ }^{1} \mathrm{H}$ NMR $\left(\mathrm{CDCl}_{3}, 500 \mathrm{MHz}\right) ; \delta$ (ppm): 5.12 (s, 2H, $\mathrm{CH}_{2}$-benzyloxy), 7.14 (d, 2H, Ar-H, J = 8.4 Hz), 7.53 (d, 2H, Ar-H, J = 8.4 Hz), 7.46-7.52 (d, 2x 2H, Ar-H, J = 8.4 Hz), 7.57 (s, 1H, Ar-H), 7.55 (s, 1H, Ar-H), 7.59 (d, 2H, Ar-H, J = 7.8 Hz), $7.72(\mathrm{~d}, 2 \mathrm{H}, \mathrm{Ar}-\mathrm{H}, J=8.4 \mathrm{~Hz}), 7.75-7.80(\mathrm{~m}$, $3 \mathrm{H}, \mathrm{Ar}-\mathrm{H}), 7.62(\mathrm{~d}, 1 \mathrm{H}$, chalcone-H, $J=15.5 \mathrm{~Hz}), 7.69(\mathrm{~d}, 1 \mathrm{H}$, chalcone-H, $15.3 \mathrm{~Hz})$, and 8.47 (s, $1 \mathrm{H}$, pyrazole-H); ${ }^{13} \mathrm{C} \mathrm{NMR}\left(\mathrm{CDCl}_{3}, 125 \mathrm{MHz}\right): \delta(\mathrm{ppm}) 70.6$ (benzyloxy-CH$\left.)_{2}\right), 113.3$, 114.6, 119.7, 125.4, 126.5, 127.2, 127.3 (chalcone-C-7), 127.6, 128.7, 129.2, 129.3, 129.7, 130.3 (pyrazole-C-5), 131.7 (C-Cl), 133.3, 135.4, 136.9, 139.7 (phenyl-C-1), 145.3 (chalcone-C-6), 146.3, 150.2 (pyrazole-C-7), 159.2, and 189.1 (C=O); ESI-MS $(m / z): 524.11\left(\mathrm{M}^{+}+1\right), 525.08$ $\left(\mathrm{M}^{+}+2\right)$, and $526.06\left(\mathrm{M}^{+}+4\right)$. Analysis calculated for $\mathrm{C}_{31} \mathrm{H}_{22} \mathrm{Cl}_{2} \mathrm{~N}_{2} \mathrm{O}_{2}: \mathrm{C}, 70.85 ; \mathrm{H}, 4.21$; and $\mathrm{N}, 5.32$. Found: C, 70.92; H, 4.18; and N, 5.41.

(E)-3-(3-(4-(benzyloxy)phenyl)-1-phenyl-1H-pyrazol-4-yl)-1-(2,4-dihydroxyphenyl)prop2-en-1-one (5n):

White buff solid, yield: $72 \%$; m.p.: $176-178{ }^{\circ} \mathrm{C}$; IR $\left(\mathrm{KBr}, \mathrm{cm}^{-1}\right): 3435(\mathrm{OH}), 3086(\mathrm{CH}$ aromatic), 2950 (CH aliphatic), $1782(\mathrm{C}=\mathrm{O}), 1620(\mathrm{C}=\mathrm{N}), 1603(\mathrm{C}=\mathrm{C})$, and $1250(\mathrm{C}-\mathrm{O}) ;{ }^{1} \mathrm{H}$ $\mathrm{NMR}\left(\mathrm{CDCl}_{3}, 500 \mathrm{MHz}\right) ; \delta$ (ppm): 5.18 (s, 2H, $\mathrm{CH}_{2}$-benzyloxy), 5.60 (s, 2H, 2x OH), 6.42 (s, $1 \mathrm{H}, \mathrm{Ar}-\mathrm{H}), 7.10(\mathrm{t}, 3 \mathrm{H}, \mathrm{Ar}-\mathrm{H}, J=6.8 \mathrm{~Hz}), 7.38(\mathrm{~d}, 2 \mathrm{H}, \mathrm{Ar}-\mathrm{H}, J=6.4 \mathrm{~Hz}), 7.46-7.64(\mathrm{~m}, 3 \mathrm{H}$, Ar-H), $7.72(\mathrm{~d}, 1 \mathrm{H}$, chalcone-H-7, $J=15.2 \mathrm{~Hz}), 7.62-7.76(\mathrm{~m}, 4 \mathrm{H}$, Ar-pyrazole $), 7.80(\mathrm{~d}, 1 \mathrm{H}$, chalcone-H-6, $J=15.8 \mathrm{~Hz}), 7.86(\mathrm{~d}, 2 \mathrm{H}, \mathrm{Ar}-\mathrm{H}, J=8.8 \mathrm{~Hz}), 7.90(\mathrm{~d}, 2 \mathrm{H}, \mathrm{Ar}-\mathrm{H}, J=7.6 \mathrm{~Hz})$, and 8.05 (s, 1H. pyrazole-H); ${ }^{13} \mathrm{C} \mathrm{NMR}\left(\mathrm{CDCl}_{3}, 125 \mathrm{MHz}\right): \delta(\mathrm{ppm}) 71.2$ (benzyloxy-CH$), 104.6$, 113.2, 113.5, 114.3, 114.7, 119.6, 125.4, 126.4, 127.8, 127.4 (chalcone-C-7), 127.5, 128.5, 128.6, 129.4, 130.4 (pyrazole-C-5), 133.5, 136.4, 139.8 (pyrazole-phenyl-C-1), 145.2 (chalcone-C-6), 150.6 (pyrazole-C-3), 159.2, $165.4\left(\mathrm{C}^{\prime}-4-\mathrm{OH}\right), 166.8\left(\mathrm{C}^{\prime}-2-\mathrm{OH}\right)$, and $192.2(\mathrm{C}=\mathrm{O})$; ESI-MS $(m / z): 488.17\left(\mathrm{M}^{+}\right)$. Analysis calculated for $\mathrm{C}_{31} \mathrm{H}_{24} \mathrm{~N}_{2} \mathrm{O}_{4}: \mathrm{C}, 76.21 ; \mathrm{H}, 4.95$; and $\mathrm{N}, 5.73$. Found: C, 76.28; $\mathrm{H}, 4.88$; and N, 5.76.

(E)-3-(3-(4-(benzyloxy)phenyl)-1-phenyl-1H-pyrazol-4-yl)-1-(3,4-dimethoxyphenyl)prop2-en-1-one (5o): 
Green solid, yield: 79\%; m.p.: 206-208 ${ }^{\circ} \mathrm{C}$; IR (KBr, $\left.\mathrm{cm}^{-1}\right): 3085$ (CH aromatic), 2955 (CH aliphatic), $1730(\mathrm{C}=\mathrm{O}), 1610(\mathrm{C}=\mathrm{N}), 1596(\mathrm{C}=\mathrm{C}), 1225\left(\mathrm{OCH}_{3}\right)$, and $1265(\mathrm{C}-\mathrm{O}) ;{ }^{1} \mathrm{H}$ $\mathrm{NMR}\left(\mathrm{CDCl}_{3}, 500 \mathrm{MHz}\right) ; \delta(\mathrm{ppm}): 3.96\left(\mathrm{~s}, 6 \mathrm{H}, \mathrm{OCH}_{3}\right), 5.12$ (s, 2H, $\mathrm{CH}_{2}$-benzyloxy), 6.91$7.97(\mathrm{~m}, 19 \mathrm{H}$, aromatic $\mathrm{H}), 7.90(\mathrm{~d}, 1 \mathrm{H}, \mathrm{CH}=\mathrm{CH}, \mathrm{Cis}, J=13 \mathrm{~Hz}), 7.7(\mathrm{~d}, 1 \mathrm{H}, \mathrm{CH}=\mathrm{CH}$, $J=9 \mathrm{~Hz})$, and $8.32\left(\mathrm{~s}, 1 \mathrm{H}, \mathrm{CH}\right.$ of pyrazole); ${ }^{13} \mathrm{C} \mathrm{NMR}\left(\mathrm{CDCl}_{3}, 125 \mathrm{MHz}\right): \delta(\mathrm{ppm}) 56.1$ $\left(\mathrm{C}^{\prime}-4-\mathrm{OCH}_{3}\right), 70.1$ (benzyloxy-CH$\left.{ }_{2}\right), 109.9$ (Pyrazole-C-4), 110.7, 115.2, 118.27, 119.33, 120.93, $122.79,125.21,126.83,127.15,127.52,128.09$, 128.68, 129.59 (Chalcone-C-7), 130.13, 131.36, 134.75 (pyrazole-C-5), 136.80, 139.50 (pyrazole-phenyl-C-1), 149.18 (chalcone-C-6), 151.15 (pyrazole-C-3), 153.51, $159.28\left(\mathrm{C}^{-} 4^{\prime}-\mathrm{OCH}_{3}\right)$, and 188.25 (C=O); ESI-MS (m/z): $517.19\left(\mathrm{M}^{+}\right)$. Analysis calculated for $\mathrm{C}_{33} \mathrm{H}_{28} \mathrm{~N}_{2} \mathrm{O}_{4}$ : C, 76.73; $\mathrm{H}, 5.46$; and $\mathrm{N}, 5.42$. Found: C, 76.78; $\mathrm{H}, 5.40$; and $\mathrm{N}, 5.48$.

(E)-3-(3-(4-(benzyloxy)phenyl)-1-phenyl-1H-pyrazol-4-yl)-1-(2,4-dimethoxyphenyl)prop2-en-1-one (5p):

Green solid, yield: 76\%; m.p.: 226-228 ${ }^{\circ} \mathrm{C}$; IR (KBr, cm-1): 3096 (CH aromatic), 2967 (CH aliphatic), $1738(\mathrm{C}=\mathrm{O}), 1625(\mathrm{C}=\mathrm{N}), 1563(\mathrm{C}=\mathrm{C}), 1245\left(\mathrm{OCH}_{3}\right)$, and $1272(\mathrm{C}-\mathrm{O}) ;{ }^{1} \mathrm{H}$ $\mathrm{NMR}\left(\mathrm{CDCl}_{3}, 500 \mathrm{MHz}\right) ; \delta$ (ppm): 3.73-3.75 (s, 6H, 2xOCH $), 5.17$ (s, 2H, $\mathrm{CH}_{2}$-benzyloxy), $7.14(\mathrm{~d}, 2 \mathrm{H}, \mathrm{Ar}-\mathrm{H}, J=8.6 \mathrm{~Hz}), 7.35$ (d, 2H, Ar-H, J = 8.1 Hz), 7.38 (s, 1H, Ar-H), 7.39-7.60 $(\mathrm{m}, 10 \mathrm{H}, \mathrm{Ar}-\mathrm{H}), 7.67$ (d, 2H, Ar-H, J = 8.7 Hz), 7.99 (d, 1H, chalcone-H-7, J = 15.3 Hz), 8.36 (s, $1 \mathrm{H}$, chalcone-H-6), and 8.54 (s, 1H. pyrazole-H); ${ }^{13} \mathrm{C} \mathrm{NMR}\left(\mathrm{CDCl}_{3}, 125 \mathrm{MHz}\right): \delta(\mathrm{ppm})$ $56.3\left(\mathrm{C}^{\prime}-4-\mathrm{OCH}_{3}\right), 69.5$ (benzyloxy- $\left.\mathrm{CH}_{2}\right), 113.4$ (pyrazole-C-4), 113.7, 114.2, 119.6, 119.1, 125.6, 126.3, 127.3, 127.65 (chalcone-C-7), 127.2, 128.3, 128.5, 129.4, 130.4 (pyrazole-C-5), 130.8, 133.7, 136.4, 139.3 (pyrazole-phenyl-C-1), 145.5 (chalcone-C-6), 150.7 (pyrazole-C-3), $151.2\left(\mathrm{C}-3^{\prime}-\mathrm{OCH}_{3}\right), 156.2\left(\mathrm{C}^{\prime} 4^{\prime}-\mathrm{OCH}_{3}\right), 159.5$, and $189.5(\mathrm{C}=\mathrm{O})$; ESI-MS $(\mathrm{m} / z): 516.20\left(\mathrm{M}^{+}\right)$. Analysis calculated for $\mathrm{C}_{33} \mathrm{H}_{28} \mathrm{~N}_{2} \mathrm{O}_{4}$ : C, 76.73; $\mathrm{H}, 5.46$; and N, 5.42. Found: C, 76.75; H, 5.38; and $\mathrm{N}, 5.45$.

(E)-3-(3-(4-(benzyloxy)phenyl)-1-phenyl-1H-pyrazol-4-yl)-1-(2-bromo-4-methoxyphenyl) prop-2-en-1-one $(5 \mathbf{q})$ :

Off white solid, yield: $56 \%$; m.p.: $174-176^{\circ} \mathrm{C}$; IR $\left(\mathrm{KBr}, \mathrm{cm}^{-1}\right): 3070$ (CH aromatic), 2938 ( $\mathrm{CH}$ aliphatic), $1765(\mathrm{C}=\mathrm{O}), 1647(\mathrm{C}=\mathrm{N}), 1588(\mathrm{C}=\mathrm{C}), 1229\left(\mathrm{C}-\mathrm{OCH}_{3}\right), 1260(\mathrm{C}-\mathrm{O})$, and $630(\mathrm{C}-\mathrm{Br}) ;{ }^{1} \mathrm{H}$ NMR $\left(\mathrm{CDCl}_{3}, 500 \mathrm{MHz}\right) ; \delta(\mathrm{ppm}): 3.82\left(\mathrm{~s}, 3 \mathrm{H}, \mathrm{OCH}_{3}\right), 5.13(\mathrm{~s}, 2 \mathrm{H}$, $\mathrm{CH}_{2}$-benzyloxy), 7.14 (d, 2H, Ar-H, J = 7.1 Hz), 7.21 (s, 1H, Ar-H), 7.38 (d, 2H, Ar-H, $J=6.4 \mathrm{~Hz}), 7.32-7.44(\mathrm{~m}, 5 \mathrm{H}, \mathrm{Ar}-\mathrm{H}), 7.48(\mathrm{~s}, 1 \mathrm{H}, \mathrm{Ar}-\mathrm{H}), 7.62(\mathrm{~d}, 2 \mathrm{H}$, Ar-pyrazole, $J=7.6 \mathrm{~Hz})$, $7.64(\mathrm{~d}, 2 \mathrm{H}, \mathrm{Ar}-\mathrm{H}, \mathrm{J}=7.6 \mathrm{~Hz}), 7.86(\mathrm{~d}, 1 \mathrm{H}$, chalcone-H-7, J = $15.5 \mathrm{~Hz}), 7.90$ (d, 2H, Ar-H, $J=7.6 \mathrm{~Hz}), 8.32(\mathrm{~d}, 1 \mathrm{H}$, chalcone-H-6, $J=16.4 \mathrm{~Hz})$, and $8.43\left(\mathrm{~s}, 1 \mathrm{H}\right.$. pyrazole-H); ${ }^{13} \mathrm{C}$ NMR $\left(\mathrm{CDCl}_{3}, 125 \mathrm{MHz}\right): \delta(\mathrm{ppm}) 56.3\left(\mathrm{C}^{\prime}-4-\mathrm{OCH}_{3}\right), 69.5$ (benzyloxy-CH$), 113.4$ (pyrazole-C-4), 113.7, 114.2, 119.6, 119.1, 125.6, 126.3, 127.3, 127.65 (chalcone-C-7), 127.2, 128.3, 128.5, 129.4, 130.4 (pyrazole-C-5), 130.8, 133.7, 136.4, 139.3 (pyrazole-phenyl-C-1), 145.5 (chalcone-C-6), 150.7 (pyrazole-C-3), $151.2\left(\mathrm{C}-3^{\prime}-\mathrm{OCH}_{3}\right), 156.2\left(\mathrm{C}-4^{\prime}-\mathrm{OCH}_{3}\right), 159.5$, and $189.5(\mathrm{C}=\mathrm{O})$; ESI-MS $(m / z)$ : $525.17\left(\mathrm{M}^{+}\right)$. Analysis calculated for $\mathrm{C}_{32} \mathrm{H}_{25} \mathrm{BrN}_{2} \mathrm{O}_{3}: \mathrm{C}, 67.97 ; \mathrm{H}, 4.46 ;$ amd N, 4.95 . Found: C, 68.02; H, 4.42; and N, 4.98 .

(E)-3-(3-(4-(benzyloxy)phenyl)-1-phenyl-1H-pyrazol-4-yl)-1-(4-(trifluoromethyl)Phenyl) prop-2-en-1-one (5r):

White buff solid, yield: $68 \%$; m.p.: $186-188^{\circ} \mathrm{C}$; IR $\left(\mathrm{KBr}, \mathrm{cm}^{-1}\right): 3075$ (CH aromatic), 2985 (CH aliphatic), $1760(\mathrm{C}=\mathrm{O}), 1650(\mathrm{C}=\mathrm{N}), 1520(\mathrm{C}=\mathrm{C})$, and 1265 (C-O), $780(\mathrm{C}-\mathrm{F})$; ${ }^{1} \mathrm{H} \mathrm{NMR}\left(\mathrm{CDCl}_{3}, 500 \mathrm{MHz}\right) ; \delta$ (ppm): 5.14 (s, 2H, $\mathrm{CH}_{2}$-benzyloxy), 7.17 (d, 2H, Ar-H, $J=7.2 \mathrm{~Hz}), 7.36(\mathrm{t}, 1 \mathrm{H}, \mathrm{Ar}-\mathrm{H}, J=7.3 \mathrm{~Hz}), 7.44-7.52(\mathrm{~m}, 5 \mathrm{H}, \mathrm{Ar}-\mathrm{H}), 7.58(\mathrm{~d}, 2 \mathrm{H}, \mathrm{Ar}-\mathrm{H}$, $J=7.5 \mathrm{~Hz}), 7.69(\mathrm{~d}, 2 \mathrm{H} \mathrm{Ar}-\mathrm{H}, J=8.4 \mathrm{~Hz}), 7.74(\mathrm{~d}, 2 \mathrm{H}, \mathrm{Ar}-\mathrm{H}, J=8.4 \mathrm{~Hz}), 7.80(\mathrm{~d}, 2 \mathrm{H}, \mathrm{Ar}-\mathrm{H}$, $J=8.7 \mathrm{~Hz}), 7.88(\mathrm{~d}, 1 \mathrm{H}$, chalcone-H-7, $J=15.6 \mathrm{~Hz}), 7.92(\mathrm{~d}, 2 \mathrm{H}, \mathrm{Ar}-\mathrm{H}, J=8.6 \mathrm{~Hz}), 8.06$ $(\mathrm{d}, 1 \mathrm{H}$, chalcone-H-6, $J=15.76 \mathrm{~Hz})$, and $8.34\left(\mathrm{~s}, 1 \mathrm{H}\right.$, pyrazole-H); ${ }^{13} \mathrm{C} \mathrm{NMR}\left(\mathrm{CDCl}_{3}, 125\right.$ $\mathrm{MHz}$ ): $\delta$ (ppm) 70.6 (benzyloxy- $\left.\mathrm{CH}_{2}\right), 113.1,114.9,119.8,124.5\left(\mathrm{C}_{-} \mathrm{F}_{3}\right), 125.4,125.7,126.2$, 127.1, 127.4 (chalcone-C-7), 127.9, 128.5, 128.8, 129.4, $130.2\left({\left.\mathrm{C}-2^{\prime}\right)}^{\prime}\right) 130.3$ (pyrazole-C-5), 136.4, 136.93 (C-4'), 139.8 (pyrazole-phenyl-C-1), 141.4, 145.7 (chalcone-C-6), 150.6 (pyrazole-C-3), 159.1, and $189.6(\mathrm{C}=\mathrm{O})$; ESI-MS $(m / z)$ : $554.17\left(\mathrm{M}^{+}+1\right)$. Analysis calculated for $\mathrm{C}_{32} \mathrm{H}_{23}$ $\mathrm{F}_{3} \mathrm{~N}_{2} \mathrm{O}_{2}$ : C, 73.27; $\mathrm{H}, 4.42$; and N, 5.34. Found: $\mathrm{C}, 73.36 ; \mathrm{H}, 4.36$; and N, 5.42. 


\subsection{Molecular Docking Simulation}

The molecular docking study of the designed molecules was carried out to assess their interaction and binding modes with the target receptors using Glide Extra precision (XP) Maestro 10.1 Schrodinger running on the Linux 64 operating system [47]. The 2D structure of the synthesized compounds was generated and then converted to their respective 3D structures using Ligprep. The PDB file of the X-ray crystal structure of the tubulin domain bound to colchicine (PDB ID:3E22) was downloaded from the RCSB Protein Data Bank. The protein preparation wizard was used to prepare the protein and the grid was generated for the co-crystal ligand using receptor grid generation. The water residues beyond $5 \AA$ were eliminated. The protein was optimized by assigning $\mathrm{H}$-bonds and the minimization of the OPLS 2005 force field. The docked pose of ligands and their interactions were analyzed after the end of the molecular docking.

\subsection{Biological Activity}

\subsubsection{In Vitro Anticancer Activity by MTT Assay}

Materials and Methods

(3-(4,5-Dimethyl-2-yl)-2,5-diphenyl tetrazolium bromide (MTT), Dulbecco's modified Eagle's medium (DMEM), $0.25 \%$ trypsin, and $0.02 \%$ EDTA mixture were purchased from HiMedia (Mumbai, India), and fetal bovine serum (FBS) was obtained from Gibco (Grand Island, NY, USA).

\section{Cell Line and Culture Conditions}

Human cervical cancer cell line SiHa, human breast cancer cell line MCF-7, human prostate cancer cell line PC-3, and human embryonic kidney HEK-293 cells were procured from the National Centre for Cell Sciences (NCCS) Pune, India. In this experiment, antibiotics (100 units/mL penicillin and $100 \mathrm{mg} \mathrm{L}^{-1}$ streptomycin were grown as a monolayer culture in Dulbecco's modified Eagle's medium containing 10\% fetal bovine serum) were cultured in a humidified atmosphere of $5 \% \mathrm{CO}_{2}$ at $37{ }^{\circ} \mathrm{C}$ in T-75 flasks and subcultured twice a week.

\section{In Vitro Cytotoxicity}

The cytotoxic effects of the selected compounds were evaluated by MTT assay [48] on the above-mentioned cell lines. Initially, $2 \times 10^{4}$ cells/well were seeded into 96-well plates $(150 \mu \mathrm{L} /$ well $)$ in triplicates and allowed to grow. The cells were incubated for $24 \mathrm{~h}$ and subsequently treated with varying concentrations of the compounds. After $48 \mathrm{~h}$, the cells were incubated with $20 \mu \mathrm{L}$ of MTT ( $5 \mathrm{mg} / \mathrm{mL}$ in PBS) in a fresh medium for $4 \mathrm{~h}$ at $37^{\circ} \mathrm{C}$. MTT is a metabolic substrate that is reduced to give formazan crystals, which were solubilized in DMSO (150 $\mu \mathrm{L} /$ well $)$ and analyzed by reading the absorbance at $540 \mathrm{~nm}$ after $15 \mathrm{~min}$ of the incubation period on the iMark Microplate Reader (Bio-Rad). Percentage viability and $\mathrm{IC}_{50}$ values were used to determine the relative absorbance of treated versus control (untreated) cells.

\subsubsection{In Vitro Tubulin Polymerization Assay}

Tubulin polymerization is a dynamic process by enhancement of fluorescence intensity due to the combination of a fluorescent reporter into the microtubules as polymerization occurs [49]. Tubulin polymerization was performed by using a purified brain tubulin polymerization kit purchased from Cytoskeleton (BK110P, Denver, CO, USA). The tubulin polymerization assay was monitored by the increase in fluorescence over a $60 \mathrm{~min}$ period at $37^{\circ} \mathrm{C}$, with excitation at $360 \mathrm{~nm}$ and emission at $450 \mathrm{~nm}$. The final buffer concentration for tubulin polymerization contained $80 \mathrm{mM}$ PIPES, $\mathrm{pH} 6.9 ; 2 \mathrm{mM} \mathrm{MgCl} 2 ; 0.5 \mathrm{mM}$ EGTA; $1 \mu \mathrm{M}$ GTP; and $15 \%$ glycerol. Firstly, $5 \mu \mathrm{L}$ of the test compounds (final concentration of $10 \mu \mathrm{M}$ ) was added and then warmed to $37^{\circ} \mathrm{C}$ for $1 \mathrm{~min}$. The reaction was initiated by adding $50 \mu \mathrm{L}$ of the tubulin reaction mix as specified for $6 \mathrm{~min}$. 


\subsubsection{In Silico Bioactivity Study}

All newly synthesized derivatives were screened for their physicochemical properties, oral bioavailability, toxicity, and online biological activity by using online software such as Molinspiration, Osiris Property Explorer, and the PASS prediction study. Hydrophobicity (c-log P), molecular weight (MW), number of rotatable bonds (NROTB) of Lipinski's rule of five [33], water solubility (c-log S), toxicity [35], and drug-likeness [34] were calculated using the online Molinspiration property calculation toolkit and online OSIRIS Property explorer. With the help of Osiris Property Explorer software, the toxicities of the synthesized derivatives were predicted, which showed that the newly synthesized compounds would be free of carcinogenicity, mutagenicity, reproductive adverse effects, and irritation. All these derivatives were also projected for their pharmacological activity by using the online PASS computer program (prediction of activity spectra for substances).

\subsection{Statistical Analysis}

Statistical analyses were performed using Graph Pad Prism 5 software. All data were analyzed by ANOVA, followed by Dunnett's multiple comparison test for $n=6$; (a) $p<0.05$ and (b) $p<0.001$. Relative to normal and data were analyzed by paired Student's $t$-test for $n=6$; (c) $p<0.0001$ and (d) $p<0.005$.

\section{Conclusions}

A series of E-3-(3-(4-(benzyloxy)phenyl)-1-phenyl-1H-pyrazol-4-yl)-1-phenylprop-2en-1-one conjugates were synthesized, characterized, and evaluated for anticancer potential and tubulin polymerization inhibition. The conjugates $5 \mathrm{~d}, 5 \mathrm{k}, 5 \mathrm{n}, 5 \mathrm{o}$, and $5 \mathrm{p}$ revealed potent cytotoxic activities against MCF-7 (human breast), SiHa (human cervical), PC-3 (human prostate), and non-cancerous cell lines using combretastatin A4 as the standard. Compound 50 displayed the most potent cytotoxic activity with the $\mathrm{IC}_{50}$ value of $2.13 \pm 0.80 \mu \mathrm{M}$ for the MCF-7 cancer cell line. Furthermore, compound $\mathbf{5 o}$ considerably arrested the cell cycle, induced apoptosis in a dose-dependent manner, and inhibited polymerization of tubulin by $66.40 \%$. Molecular docking studies of compound $5 \mathbf{o}$ (highest docking score of -7.22 ) showed that the colchicine-binding site of tubulin established promising interactions with ASN 249, ALA 250, LYS 254, SER 178, and TYR 224, and pi-cation interaction with LYS 352 in the active site of tubulin. The in silico bioactivity study and PASS prediction studies exposed that most of the synthesized compounds displayed excellent physicochemical properties within the ideal range. These results established that compound 50 is a newer tubulin polymerization inhibitor and is commendable of advanced investigation in the future, directing to the progress of newer potential anticancer agents. Therefore, these conjugates can further be structurally modified to promote a new potential target for the optimization and development of anticancer agents.

Supplementary Materials: The following are available online at https:/ /www.mdpi.com/article/10 $.3390 / \mathrm{ph} 15030280 / \mathrm{s} 1$, Figure S1: ${ }^{1} \mathrm{H}$ NMR of (E)-3-(3-(4-(benzyloxy)phenyl)-1-phenyl-1H-pyrazol-4yl)-1-(3,4-dimethoxyphenyl)prop-2-en-1-one; Figure S2: ${ }^{13} \mathrm{C}$ NMR of (E)-3-(3-(4-(benzyloxy)phenyl)-1phenyl-1H-pyrazol-4-yl)-1-(3,4-dimethoxyphenyl)prop-2-en-1-one; Figure S3: ${ }^{1} \mathrm{H}$ NMR of (E)-3-(3-(4(benzyloxy)phenyl)-1-phenyl-1H-pyrazol-4-yl)-1-(3,4-dimethoxyphenyl)prop-2-en-1-one; Figure S4: ${ }^{13} \mathrm{C}$ NMR of (E)-3-(3-(4-(benzyloxy)phenyl)-1-phenyl-1H-pyrazol-4-yl)-1-(3,4-dimethoxyphenyl)prop2-en-1-one; Figure S5: Mass spectra of (E)-3-(3-(4-(benzyloxy)phenyl)-1-phenyl-1H-pyrazol-4-yl)1-(3,4-dimethoxyphenyl)prop-2-en-1-one; Figure S6: ${ }^{1} \mathrm{H}$ NMR of (E)-3-(3-(4-(benzyloxy)phenyl)1-phenyl-1H-pyrazol-4-yl)-1-(4-bromophenyl)prop-2-en-1-one; Figure S7: ${ }^{1} \mathrm{H}$ NMR of (E)-3-(3-(4(benzyloxy)phenyl)-1-phenyl-1 $H$-pyrazol-4-yl)-1-(4-bromophenyl)prop-2-en-1-one; Figure S8: ${ }^{13} \mathrm{C}$ NMR of (E)-3-(3-(4-(benzyloxy)phenyl)-1-phenyl-1H-pyrazol-4-yl)-1-(4-bromophenyl)prop-2-en-1-one; Figure S9: Mass spectra of (E)-3-(3-(4-(benzyloxy)phenyl)-1-phenyl-1H-pyrazol-4-yl)-1-(4-bromophenyl) prop-2-en-1-one; Figure S10: ${ }^{1} \mathrm{H}$ NMR of (E)-3-(3-(4-(benzyloxy)phenyl)-1-phenyl-1H-pyrazol-4yl)-1-(4-methoxyphenyl)prop-2-en-1-one; Figure S11: ${ }^{13} \mathrm{C}$ NMR of (E)-3-(3-(4-(benzyloxy)phenyl)1-phenyl-1H-pyrazol-4-yl)-1-(4-methoxyphenyl)prop-2-en-1-one; Figure S12: ${ }^{1} \mathrm{H}$ NMR of (E)-3-(3(4-(benzyloxy)phenyl)-1-phenyl-1H-pyrazol-4-yl)-1-(4-methoxyphenyl)prop-2-en-1-one; Figure S13: 


\begin{abstract}
${ }^{13} \mathrm{C}$ NMR of (E)-3-(3-(4-(benzyloxy)phenyl)-1-phenyl-1H-pyrazol-4-yl)-1-(4-methoxyphenyl)prop-2en-1-one; Figure S14: Mass spectra of (E)-3-(3-(4-(benzyloxy)phenyl)-1-phenyl-1H-pyrazol-4-yl)-1-(4methoxyphenyl)prop-2-en-1-one; and Figure S15: Effect of lead conjugates $\mathbf{5 d}, \mathbf{5 e}, \mathbf{5 i}, \mathbf{5 k}, \mathbf{5 1}, \mathbf{5 m}, \mathbf{5 n}$, $50,5 p$, and $5 \mathrm{r}$ on tubulin polymerization. Tubulin polymerization was monitored by the increase in fluorescence at $360 \mathrm{~nm}$ (excitation) and $420 \mathrm{~nm}$ (emission) for $1 \mathrm{~h}$ at $37^{\circ} \mathrm{C}$. Combretastatin A- 4 was used as the reference standard in this study.
\end{abstract}

Author Contributions: Conceptualization, O.A. and M.J.A.; methodology, M.J.A., A.P., M.A.R., M.J.N. and V.G.M.N.; software, M.I.; validation, S.A., M.M.G. and F.S.; formal analysis, M.I.; investigation, M.I., S.A. and F.S.; resources, O.A.; data curation, M.J.A.; writing-original draft preparation, O.A. and M.J.A.; writing-review and editing, S.A., F.S. and M.I.; visualization, O.A.; supervision, O.A.; project administration, O.A.; funding acquisition, S.A. and M.M.G. All authors have read and agreed to the published version of the manuscript.

Funding: This research received no external funding.

Institutional Review Board Statement: Not applicable.

Informed Consent Statement: Not applicable.

Data Availability Statement: Data is contained within the article and supplementary material.

Acknowledgments: The authors are thankful to Jamia Hamdard, New Delhi, India, for providing facilities for research work as well as for spectral and elemental studies. One of the authors (Md. Jahangir Alam) expresses thanks to the University Grant Commission (UGC), New Delhi, India, for getting Moulana Azad the National Fellowship as financial assistance (201213-MANF-201213-MUS-BIH-17183). The corresponding author (Ozair Alam) is also thankful to DST-SERB (file no. SB/FT/LS-203-2012), New Delhi, for providing funds to purchase Schrodinger software USA (molecular modeling).

Conflicts of Interest: The authors declare no conflict of interest.

\title{
References
}

1. Frankish, H. 15 million new cancer cases per year by 2020, says WHO. Lancet 2003, 361, 1278. [CrossRef]

2. American Cancer Society. American Cancer Society: Cancer Facts and Figures 2016; American Cancer Society: Atlanta, GA, USA, 2016.

3. Available online: https://www.who.int/news-room/fact-sheets/detail/cancer (accessed on 15 September 2021).

4. Belpomme, D.; Irigaray, P.; Sasco, A.J.; Newby, J.A.; Howard, V.; Clapp, R.; Hardell, L. The growing incidence of cancer: Role of lifestyle and screening detection (review). Int. J. Oncol. 2007, 30, 1037-1049. [CrossRef]

5. Kibria, G.; Hatakeyama, H.; Harashima, H. Cancer multidrug resistance: Mechanisms involved and strategies for circumvention using a drug delivery system. Arch. Pharm. Res. 2014, 37, 4-15. [CrossRef]

6. Negi, A.S.; Gautam, Y.; Alam, S.; Chanda, D.; Luqman, S.; Sarkar, J.; Khan, F.; Konwar, R. Natural anti-tubulin agents: Importance of 3,4,5-trimethoxyphenyl fragment. Bioorg. Med. Chem. 2015, 23, 373-389. [CrossRef]

7. Vindya, N.G.; Sharma, N.; Yadav, M.; Ethiraj, K.R. Tubulins-The target for anticancer therapy. Curr. Top. Med. Chem. 2015, 15, 73-82. [CrossRef]

8. Barbier, P.; Tsvetkov, P.O.; Breuzard, G.; Devred, F. Deciphering the molecular mechanisms of anti-tubulin plant-derived drugs. Phytochem. Rev. 2014, 13, 157-169. [CrossRef]

9. Field, J.J.; Kanakkanthara, A.; Miller, J.H. Microtubule-targeting agents are clinically successful due to both mitotic and interphase impairment of microtubule function. Bioorg. Med. Chem. 2014, 22, 5050-5059. [CrossRef]

10. Pettit, G.R.; Cragg, G.M.; Herald, D.L.; Schmidt, J.M.; Lohavanijaya, P. Isolation, and structure of combretastatin. Can. J. Chem. 1982, 60, 1374-1376. [CrossRef]

11. Ravelli, R.B.; Gigant, B.; Curmi, P.A.; Jourdain, I.; Lachkar, S.; Sobel, A.; Knossow, M. Insight into tubulin regulation from a complex with colchicine and a stathmin-like domain. Nature 2004, 428, 198-202. [CrossRef]

12. Bohlin, L.; Rosen, B. Podophyllotoxin derivatives: Drug discovery and development. Drug Discov. Today 1996, 1, 343-351. [CrossRef]

13. Kuehne, M.E.; Marko, I.; Brossi, A. (Eds.) The Alkaloids; Academic Press: San Diego, CA, USA, 1990; Volume 37, pp. 77-132.

14. Jimenez, C.; Ellahioui, Y.; Alvarez, R.; Aramburu, L.; Riesco, A.; Gonzalez, M.; Vicente, A.; Dandouh, A.; Ibn Mansour, A.; Jimenez, C.; et al. Exploring the size adaptability of the B ring binding zone of the colchicine site of the tubulin with para-nitrogen substituted isocombretastatins. Eur. J. Med. Chem. 2015, 100, 210-222. [CrossRef]

15. Nickel, H.C.; Schmidt, P.; Bohm, K.J.; Baasner, S.; Muller, K.; Gerlach, M.; Unger, E.; Gunthe, E.G.; Prinz, H. Synthesis, antiproliferative activity and inhibition of tubulin polymerization by 1,5- and 1,8-disubstituted $10 \mathrm{H}$-anthracen-9-ones bearing a 10-benzylidene or 10-(2-oxo-2-phenylethylidene) moiety. Eur. J. Med. Chem. 2010, 45, 3420-3438. [CrossRef] 
16. Pellegrini, F.; Budman, D.R. Review: Tubulin function, action of anti-tubulin drugs, and new drug development. Cancer Investig. 2005, 23, 264-273. [CrossRef]

17. Tron, G.C.; Pagliai, F.; Del Grosso, E.; Genazzani, A.A.; Sorba, G. Synthesis and cytotoxic evaluation of combretafurazans. J. Med. Chem. 2005, 48, 3260-3268. [CrossRef]

18. Doi, S.; Fujioka, N.; Ohtsuka, S.; Kondo, R.; Yamamoto, M.; Denda, M.; Magari, M.; Kanayama, N.; Hatano, N.; Morishita, R.; et al. Regulation of the tubulin polymerization-promoting protein by Ca2+/S100 proteins. Cell Calcium. 2021, 96, 102404. [CrossRef]

19. Liu, W.; Wang, G.; Peng, Z.; Li, Y. Design, synthesis and biological evaluation of novel 4-(4-methoxynaphthalen-1-yl)-5arylpyrimidin-2-amines as tubulin polymerization inhibitors. Chem. Pharm. Bull. 2020, 68, 1184-1192. [CrossRef]

20. Kamal, A.; Kumar, G.B.; Vishnuvardhan, M.V.P.S.; Shaik, A.B.; Reddy, V.S.; Mahesh, R.; Sayeeda, I.B.; Kapure, J.S. Synthesis of phenstatin/isocombretastatin-chalcone conjugates as potent tubulin polymerization inhibitors and mitochondrial apoptotic inducers. Org. Biomol. Chem. 2015, 13, 3963-3981. [CrossRef]

21. Nakagawa-Goto, K.; Oda, A.; Hamel, E.; Ohkoshi, E.; Lee, K.-H.; Goto, M. Development of a novel class of tubulin inhibitor from desmosdumotin B with a hydroxylated bicyclic B-ring. J. Med. Chem. 2015, 58, 2378-2389. [CrossRef]

22. Kumar, V.; Kaur, K.; Gupta, G.K.; Sharma, A.K. Pyrazole containing natural products: Synthetic preview and biological significance. Eur. J. Med. Chem. 2013, 69, 735-753. [CrossRef]

23. Harras, M.F.; Sabour, R. Design, synthesis and biological evaluation of novel 1, 3, 4-trisubstituted pyrazole derivatives as potential chemotherapeutic agents for hepatocellular carcinoma. Bioorg. Chem. 2018, 78, 149-157. [CrossRef]

24. Kumar, H.; Saini, D.; Jain, S.; Jain, N. Pyrazole scaffold: A remarkable tool in the development of anticancer agents. Eur. J. Med. Chem. 2013, 70, 248-258. [CrossRef] [PubMed]

25. Liu, Y.R.; Luo, J.Z.; Duan, P.P.; Shao, J.; Zhao, B.X.; Miao, J.Y. Synthesis of pyrazole peptidomimetics and their inhibition against A549 lung cancer cells. Bioorg. Med. Chem. Lett. 2012, 22, 6882-6887. [CrossRef] [PubMed]

26. Shah, K.; Chhabra, S.; Shrivastava, S.K.; Mishra, P. Benzimidazole: A promising pharmacophore. Med. Chem. Res. 2013, 22, 5077-5104. [CrossRef]

27. Narasimhan, B.; Sharma, D.; Kumar, P. Benzimidazole: A medicinally important heterocyclic moiety. Med. Chem. Res. 2012, 21, 269-283. [CrossRef]

28. Sharp, S.Y.; Boxall, K.; Rowlands, M.; Prodromou, C.; Roe, S.M.; Maloney, A.; Powers, M.; Clarke, P.A.; Box, G.; Sanderson, S.; et al. In vitro biological characterization of a novel, synthetic diaryl pyrazole resorcinol class of heat shock protein 90 inhibitors. Cancer Res. 2007, 67, 2206-2216. [CrossRef] [PubMed]

29. Peyrot, V.; Leynadier, D.; Sarrazin, M.; Briand, C.; Menendez, M.; Laynez, J.; Andreu, J.M. Mechanism of binding of the new antimitotic drug MDL 27048 to the colchicine site of tubulin: Equilibrium studies. Biochemistry 1992, 31, 11125-11132. [CrossRef] [PubMed]

30. Kamal, A.; Shaik, A.B.; Jain, N.; Kishor, C.; Nagabhushana, A.; Supriya, B.; Kumar, G.B.; Chourasiya, S.S.; Suresh, Y.; Mishra, R.K Design and synthesis of pyrazole-oxindole conjugates targeting tubulin polymerization as new anticancer agents. Eur. J. Med. Chem. 2013, 92, 501-513. [CrossRef]

31. Yang, X.H.; Wen, Q.; Zhao, T.T.; Sun, J.; Li, X.; Xing, M.; Lu, X.; Zhu, H.L. Synthesis, biological evaluation, and molecular docking studies of acyl 1,3,4-thiadiazole amide derivatives as novel anti-tubulin agents. Bioorg. Med. Chem. 2012, 20, 1181-1187. [CrossRef]

32. Srinivasa, R.T.; Ganga, R.V.; Kulhari, H.; Shukla, R.; Kamal, A.; Bansal, V. Synthesis of Z-1-(1,3-diphenyl-1H-pyrazol-4-yl)-3(phenylamino)prop-2-en-one derivatives as potential anticancer and apoptosis inducing agents. Eur. J. Med. Chem. 2016, 117, 157-166. [CrossRef]

33. Kamal, A.; Shaik, A.B.; Bhaskara, R.B.; Khan, I.; Kumara, G.B.; Jainc, N. Design and synthesis of pyrazole/isoxazole linked arylcinnamides as tubulin polymerization inhibitors and potential antiproliferative agents. Org. Biomol. Chem. 2015, 40, 10162-10178. [CrossRef]

34. Nam, N.H. Combretastatin A-4 analogues as antimitotic antitumor agents. Curr. Med. Chem. 2003, 10, 1697-1722. [CrossRef] [PubMed]

35. Paul, K.; Bindal, S.; Luxami, V. Synthesis of new conjugated coumarin-benzimidazole hybrids and their anticancer activity. Bioorg. Med. Chem. 2013, 15, 3667-3672. [CrossRef] [PubMed]

36. Lagunin, A.; Stepanchikova, A.; Filimonov, D.; Poroikov, V. PASS: Prediction of activity spectra for biologically active substances Bioinformatics 2000, 16, 747-748. [CrossRef] [PubMed]

37. PASS Software Free Molecular Property Calculation Services. Available online: http://www.pharmaexpert.ru/passonline/ predict.php (accessed on 15 February 2019).

38. Mosmann, T.J. Rapid colorimetric assay for cellular growth and survival: Application to proliferation and cytotoxicity assays Immunol. Methods 1983, 65, 55-63. [CrossRef]

39. Kaushik, D.; Khan, S.A.; Chawla, G.; Kumar, S. N'-[(5-chloro-3-methyl-1-phenyl-1H-pyrazol-4-yl)methylene] 2/4-substituted hydrazides: Synthesis and anticonvulsant activity. Eur. J. Med. Chem. 2010, 45, 3943-3949. [CrossRef] [PubMed]

40. Ragab, F.A.; Abdel Gawad, N.M.; Georgey, H.H.; Said, M.F. Synthesis of novel 1,3,4-trisubstituted pyrazoles as anti-inflammatory and analgesic agents. Eur. J. Med. Chem. 2013, 63, 645-654. [CrossRef]

41. Mehdi, S.J.; Ahmad, A.; Irshad, M.; Manzoor, N.; Rizvi, M.M.A. Cytotoxic effect of carvacrol on human cervical cancer cells. Biol. Med. 2011, 2, 307-312. 
42. Kamal, A.; Srinivasa, R.T.; Vardhan, V.; Kumar, V.; Nimbarte, D.; Subba, A.V.R.; Srinivasulu, V.; Shankaraiah, N. Synthesis of 2-aryl-1,2,4-oxadiazolo-benzimidazoles: Tubulin polymerization inhibitors and apoptosis inducing agents. Bioorg. Med. Chem. 2015, 23, 4608-4623. [CrossRef]

43. LLC. Schrodinger, Maestro, Version 10.1; LLC: New York, NY, USA, 2018.

44. Huang, X.F.; Lu, X.; Zhang, Y.; Song, G.Q.; He, Q.L.; Li, Q.S.; Yang, X.H.; Wei, Y.; Zhu, H.L. Synthesis, biological evaluation, and docking studies of $\mathrm{N}-((1,3$-diphenyl-1H-pyrazol-4yl)methyl)aniline derivatives as novel anticancer agents. Bioorg. Med. Chem. 2012, 20, 4895-4900. [CrossRef]

45. Hou, T.; Wang, J.; Zhang, W.; Xu, X.J. ADME evaluation in drug discovery. 6. Can oral bioavailability in humans be effectively predicted by simple molecular property-based rules? Chem. Inf. Model. 2007, 47, 460-463. [CrossRef]

46. Molinspiration Software or Free Molecular Property Calculation Services (2 Screens). Available online: www.molinspiration. com/cgi-bin/properties (accessed on 15 February 2021).

47. Sander, T. Osiris Property, Explore. 2001. Available online: http://www.organic-chemistry.org/prog/peo/ (accessed on 15 February 2018).

48. Meanwell, N.A. Improving drug candidates by design: A focus on physicochemical properties as a means of improving compound disposition and safety. Chem. Res. Toxicol. 2011, 24, 1420-1456. [CrossRef] [PubMed]

49. Hopkins, A.L.; Keserü, G.M.; Leeson, P.D.; Rees, D.C.; Reynolds, C.H. The role of ligand efficiency metrics in drug discovery. Nat. Rev. Drug Discov. 2014, 13, 105-121. [CrossRef] [PubMed] 